\title{
The Importance of Appearing Principled
}

\author{
Deborah Hellman*
}

Table of Contents

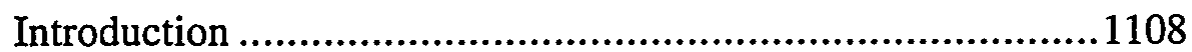

I. A Brief Offer of Proof....................................................1109

A. Stare Decisis Doctrine Generally .................................1109

B. The Traditional Conception...........................................1112

C. The Prudential Conception...........................................1115

D. Addendum: Webster ...............................................1120

II. Should the Court Consider Appearance?................................1121

A. Permission ...........................................................1123

1. The General Argument .........................................1124

2. Commitment to Judicial Independence .....................1127

3. Not a "Legal" Consideration ...................................1130

a. Permitted by Some Normative

Theories of Adjudication.........................................1130

i. Critical Legal Studies and

Law and Economics......................................1131

ii. Theories That Maintain a Robust

Law-Politics Distinction....................................1132

iii. Hybrid Theories ..................................................1133

iv. Prudential Theories..........................................1134

v. Structural Theories ............................................1135

vi. Textual Theories.................................................1135

vii. Summary of the Argument Thus Far ..................1136

b. Adding Factors Affects Outcomes ...........................1137

B. All Things Considered...............................................1139

1. Effectiveness Is Necessary

for Legitimate Authority .........................................1139

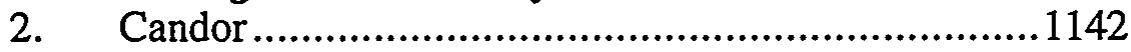

a. Prima Facie Obligation ........................................1142

b. Collegiality and the Co-Signed Opinion.......................1143

c. Paternalism and Self-Paternalism .............................1144

* Assistant Professor, University of Maryland School of Law.

I want to thank the William H. Keck Foundation and the Harvard Program in Ethics and the Professions for their generous support while I worked out the ideas presented here. In addition, I would like to thank Arthur Applbaum, Marie-Claire Belleau, Richard Fallon, David Luban, and Alan Wertheimer for their comments and criticism of earlier drafts. My research assistants, Jessica Collins and Daniel Ginsburg, provided excellent research assistance. Most of all, I am indebted to David Wilkins for his continuous support and encouragement with this and many other endeavors. 
d. The Argument from Mystique ...............................1145

3.

Self-Defeating .........................................................1146

4. Historical........................................................1148

5. Neo-Prudentialism............................................1151

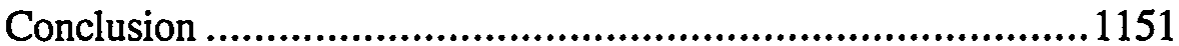

\section{INTRODUCTION}

Appearance is often construed as something negative. It is mere appearance; this expression highlighting the derision with which the defenders of the real view the purveyors of image. The words to live by are that appearances deceive. It is an ancient insight. Socrates, in Plato's Gorgias, warns against the dangers of rhetoric: in the same way as cosmetics produce only a seeming beauty where exercise and training produce actual improvements in bodily form, so too oratory only flatters the soul, Socrates counsels, while politics and philosophy can improve it. ${ }^{1}$ Today, children continue to be taught, "don't judge a book by its cover." Of course appearances do not always belie that which they are the appearances of. But the wisdom reflected in the maxim above admonishes that it is the substance (of the body, the soul, the book) that is important, and but a happy coincidence when the appearance of a thing is of the same normative significance as the thing itself. Handsome is as handsome does.

There is thus a paradoxical air to the claim that appearance itself is important, normatively speaking. Interestingly, Supreme Court opinions increasingly adopt such a view. ${ }^{2}$ These decisions claim that an opinion must look principled as well as be principled in order to legitimately and justifiably fulfill the judicial function. This article will defend the initially counterintuitive claim that the approach currently being adopted by the Court is the correct one; the Court should attend to its appearance.

Part I of the article offers a brief documentation of the Court's growing concern with appearing principled. This documentation consists of an examination of a development in stare decisis doctrine. Stare decisis provides fertile ground for this analysis because the recognition of the importance to the Court of appearing principled has always been part of the rationale for that doctrine, though previously this has been recognized, for the most part, by commentators only. Now, the role that stare decisis doctrine plays in maintaining the Court's image is being recognized in judicial opinionssometimes as part of the rationale for the doctrine and sometimes as a factor to be incorporated in the application of the doctrine.

Part II of the article examines this phenomenon. It argues that the Court ought to consider whether or not a decision will be perceived as principled, when reaching a result. It is a two-step argument. First, Part II addresses whether courts are permitted to consider the likely effect on the esteem in which the Court is held. And second, this Part addresses the question of whether the Court ought, all things considered, to do so. The argument from permission begins with the claim that the judicial role, properly understood, includes the obligation to preserve and maintain an image of the Court as a principle-guided institution. The judicial role requires that judges do more than

1. PLATO, GoRGIAS § 465b-c (Donald J. Zeyl trans., 1987).

2. See infra part I.C. 
simply decide cases, it requires that judges justify their decisions. Justification in the judicial context involves the giving of reasons to others. Thus, in order for a decision to be justificatory, it must not only be well-reasoned and wellgrounded, but also must appear so to those to whom it is addressed. Moreover, it must be based on reasons that others can be expected to accept as reasons (though not necessarily as the best reasons) for the case at hand.

The second section of Part II makes the argument that the Court must take care to safeguard its ability to be effective. Because the Court's power depends on its ability to engender respect for its authority, guarding its image is a way of protecting its ability to be effective. This section argues that in order for the Court to legitimately compel compliance with its directives in individual cases, it must have enough power to compel compliance over the run of cases. Now, clearly our judiciary is not in danger of wide-spread noncompliance with its directives. The argument offered in this section is hypothetical and normative. If being generally effective is a normatively necessary requirement of the legitimate exercise of authority by the Court, then the Court has a reason to act to protect that power.

\section{Part I: A Brief Offer of Proof}

\section{A. Stare Decisis Doctrine Generally}

Stare decisis doctrine is at present undergoing a change. It is evolving from what I will call the traditional conception of stare decisis, in which the effect of Court action on the Court's image plays no direct role (at least that is explicitly recognized) in deciding when an old case may be overruled, to what I call the prudential conception of stare decisis, in which the Court treats the effect of a decision on the esteem in which the Court is held as a significant factor to be weighed in the analysis. There is thus an emerging concern with how Court action will be perceived. Broadly speaking, the doctrine of stare decisis expresses a respect for the earlier pronouncements of the Court. Overruling prior Supreme Court cases is to be approached carefully. Judges and commentators traditionally support this deference to already decided cases by appeal to the following values: consistency, stability and predictability in the administration of the law. ${ }^{3}$ These are the purposes that are repeatedly mentioned as providing the rationale for the doctrine. ${ }^{4}$ Thus, although a wrongly decided case may be overruled, the Court must have very good reasons for doing so. Under current doctrine, the overruling of constitutional cases requires less compelling reasons than are needed in statutory cases 5 (because citizens can more easily "overrule" the earlier statutorily-based decision themselves). But even in constitutional cases "the doctrine of stare decisis demands special justification"6 for overruling.

Stare decisis doctrine is and has been notably lacking in useful standards or clear criteria articulating when an old rule may be abandoned. Instead, the doctrine resembles a constellation of values that judges are supposed to consider in making a determination of whether an older erroneous case may be

3. See, e.g., Thomas v. Washington Gas Light Co., 448 U.S. 261, 272 (1980).

4. See infra notes 21-26 and accompanying text.

5. See Patterson v. McLean Credit Union, 491 U.S. 164, 172-73 (1989).

6. Arizona v. Rumsey, 467 U.S. 203, 212 (1984). 
overruled. The doctrine provides little guidance about whether these values provide an exhaustive list of the relevant factors nor much direction about how these factors are to be balanced against one another or against other concerns. ${ }^{7}$ In other words, the doctrine is doing very little work. There has not been much translation of the justification for stare decisis into a form that is more actionguiding (more rule-like) than a statement of the justification itself provides. ${ }^{8} \mathrm{As}$ Richard Wasserstrom commented in 1961 about the then-current state of legal scholarship about the doctrine, stare decisis amounts to the rule that "precedents ought always to be followed except when they should not." 9

While this was undoubtedly an overstatement then (as Wasserstrom acknowledges), ${ }^{10}$ what truth there was in it then remains today. While there is consensus about what values (articulated at a high level of generality or abstractness) the doctrine is meant to promote (consistency and stability of law, protecting the reliance interests of those who have followed existing law and, at times, promoting an image of the legal system as principled and rule-bound), 11 there is little agreement about how much these values matter, how they can best be achieved and which among them is most important. Centrally, there is a lack of agreement about how to weigh these values against the harm that may be caused both to individuals and to the legal system through bad, old law remaining active.

A confluence of three characteristics about stare decisis make it an interesting and provocative place in which to explore the Court's growing concern with appearance. First, because the doctrine is especially unrule-like, its application is particularly likely to create the impression that the Court's decision is the product of pure discretion, ungoverned by legal norms-an impression that can be threatening to the perceived institutional integrity of the Court. ${ }^{12}$ Second, overruling itself seems to raise the specter of judicial

7. Generally, I would agree with Judge Easterbrook's deflationary characterization of the doctrine of stare decisis as "a grand balancing test, with neither a maximand nor weights to produce a decision when the criteria conflict, as they always do." Frank H. Easterbrook, Stability and Reliability in Judicial Decisions, 73 CORNELL L. REV. 422, 422 (1988).

8. For a discussion of the way in which norms translate the background justifications for the norms into forms that are more rule-like than the justification for the norm itself, see FREDERICK SCHAUER, PLAYING BY THE RULES 53-64 (1991).

9. RICHARD A. WASSERSTOM, THE JUDICIAL DECISION 46 (1961).

10. Id.

11. See ARTHUR J. GOLDBERG, EQUAL JUSTICE 75-76 (1971) ("stare decisis fostered public confidence in the judiciary and public acceptance of individual decisions by giving the appearance of impersonal, consistent, and reasoned opinions,....induced in fact a greater impersonality of decision,...facilitates private ordering,...eases the judicial burden...[and eliminates] unfair surprise and unequal treatment").

12. See Mitchell v. W. T. Grant Co., 416 U.S. 600, 636 (1974) (Stewart, J., dissenting); Pollock v. Farmers' Loan \& Trust Co., 157 U.S. 429, 650-52 (1895) (White, J., dissenting) ("The fundamental conception of a judicial body is that of one hedged about by precedents which are binding on the court without regard to the personality of its members. Break down this belief in judicial continuity, and let it be felt that on great constitutional questions this court is to depart from the settled conclusions of its predecessors, and to determine them all according to the mere opinions of those who temporarily fill its bench, and our constitution will, in my judgment, be bereft of value, and become a most dangerous instrument to the rights and liberties of the people."). See also Çharles J. Cooper, Stare Decisis: Precedent and Principle in Constitutional Adjudication, 73 CO'RNELL L. REV. 401, 402 (1988) (expressing deep cynicism about the principled character of the Court's application of the doctrine: "The truth, of course, is that stare decisis has always been a doctrine of convenience, to both conservatives and liberals."); Lawrence C. Marshall, "Let Congress Do It": The Case for an 
illegitimacy. ${ }^{13}$ The more overruling there is, the less confidence the public may have in the correctness of current decisions. Moreover, overruling of recent precedents seems to especially highlight the diversity of the views held by justices about the right answers to legal questions, which in turn may foster an image of judging as unconstrained by legal doctrine. ${ }^{14}$ While judging may in fact be unconstrained by legal norms (as some critical scholars believe), creating the impression that this is so remains delegitimating. 15

Finally, stare decisis doctrine has often been understood by commentators as serving the important purpose of helping to maintain the public's faith in the judiciary. ${ }^{16}$ However, until recently, this rationale for the doctrine has only been explicitly recognized in judicial opinions infrequently.17 By examining stare decisis cases, we can thus observe the concern with appearance surfacing in doctrine. This part of the rationale-which was before recognized predominantly by commentators-is being adopted by courts.

Absolute Rule of Statutory Stare Decisis, $88 \mathrm{MrCH}$. L. REV. 177, 179 (1989) (arguing that because there is great uncertainty about what the doctrine requires, it is very difficult to know when and whether it is being applied correctly).

13. See generally ROBERTO M. UNGER, THE CRITICAL LEGAL STUDIES MOVEMENT 89 (1983) (arguing that a method of legal analysis that requires too much revision of existing law "forfeits [the] claim to be doing doctrine as opposed to ideology, philosophy, or prophecy." Of course, for Unger, this critique of the ability of a lawyer, judge, or theorist to settle on the "right" amount of revision of existing doctrine forms part of his critique of objectivism. See id. at 5-8; Suzanna Sherry, The Eleventh Amendment and Stare Decisis: Overruling Hans v Louisiana, 57 U. CHI. L. REV. 1260, 1262-63 (1990) (arguing that "departures from stare decisis endanger the perceived legitimacy of the Court. By giving the impression that one group of Justices is merely substituting its own will for that of an earlier group of Justices, overruling well-established precedent undermines the public perception of the Court as a neutral and disinterested decisionmaker.").

14. See Garcia v. San Antonio Metro. Transit Auth., 469 U.S. 528, 559 (1985) (Powell, J., dissenting) ("The stability of judicial decision, and with it respect for the authority of this Court, are not served by the precipitate overruling of multiple precedents that we witness in these cases."); Jerold H. Israel, Gideon v. Wainwright: The "Art" of Overruling, 1963 S. CT. REV. 211, 218 (arguing that overruling generally "will tend to emphasize the subjective elements in judicial review by focusing attention on the background and personal philosophies of the various justices" and that this phenomenon is "especially true when the change in the law has occurred over a comparatively short period of time marked by a significant alteration in the Court's personnel.").

15. See generally UNGER, supra note 13, at 11 . Unger argues that "a doctrinal practice that puts its hope in the contrast of legal reasoning to ideology, philosophy, and political prophecy ends up as a collection of makeshift apologies." Id. Critical jurists believe that judging is generally unconstrained by legal doctrine and ought to be exposed as such. The process of opinion writing that presents results as constrained by the legal material is therefore best described as "legitimation."

The point for our purposes is not whether the process of judging is constrained or unconstrained nor, if constrained, how and in what way; rather, the point is to note that appearing unconstrained delegitimates judicial power (which to the critical jurist may be a welcomed outcome). Judges write as if the law/politics distinction were either more meaningful or more simplistic than academic audiences accept; i.e., there is still great rhetorical power in presenting the two as distinctly separable realms.

16. See GOLDBERG, supra note 11, at 75-76; Michael J. Gerhardt, The Role of Precedent in Constitutional Decisionmaking and Theory, 60 GEO. WASH. L. REV. 68, 143 (1991); John Wallace, Stare Decisis and the Rehnquist Court: The Collision of Activism, Passivism and Politics in Casey, 42 BUFF. L. REV. 187, 199-201 (1994); Israel, supra note 14, at 217-19; Earl Maltz, The Nature of Precedent, 66 N.C. L. REV. 367, 371-72 (1988).

17. One of the early cases to explicitly recognize this appearance concern is Moragne v. States Marine Lines, Inc., 398 U.S. 375, 403 (1970). See discussion infra at note 69. 
Let me be clear about what I am claiming. The doctrine of stare decisis has from time to time (mostly in the academic literature) been understood as justified in part by its role in promoting the appropriate image of the Court. Interestingly however, the effect on the Court's image has not been mentioned by judges employing the doctrine-until recently. This is changing. Majority opinions are increasingly calling attention to the importance of maintaining the public's faith in the Court as a principle-guided institution as a rationale for the doctrine and as a factor that may influence how the doctrine is employed.18 Dissenting judges always did (again, from time to time) lament the effect of a perceived misapplication of the stare decisis doctrine on the image of the Court. But now, the character and frequency of these lamentful dissents is also changing. The dissenters now argue not only that the misapplication of the doctrine by the majority will have the unfortunate consequence of eroding public confidence in the court, but also that the Court ought to pay attention to how its decisions will affect that image. 19

In what follows, I will sketch out the paradigms I have in mind: the "traditional stare decisis" and the "prudential stare decisis" which is, increasingly, coming to replace the traditional approach. Overruling is often done without the benefit of a stare decisis analysis at all. Moreover, when the doctrine is discussed, considered and employed, the treatment of it by the Court is often cursory. In fact, it is extremely rare to find an extensive discussion of the doctrine at all. Therefore, we ought to pay special attention to those instances where such a discussion is found. One of the recent cases employing the prudential conception, Planned Parenthood $v$. Casey, 20 contains such a discussion and thus is of particular importance. In what follows I will document this growing concern with the public perception of the Court in stare decisis doctrine, leaving for Part II the analysis of the acceptability and significance of this practice.

\section{B. The Traditional Conception}

The purpose of stare decisis doctrine is, according to the "traditional conception," to protect reliance interests and to insure the stable and consistent administration of the law. It promotes "orderly adjudication" and serves the goals of "evenhanded, consistent, and predictable application of legal rules." 21 In deciding whether to overrule what is believed to be an erroneous earlier decision, the judge ought to consider whether there has been substantial reliance

18. See infra part I.C.

19. See, e.g., Quill Corp. v. North Dakota ex rel. Heitkamp, 112 S. Ct. 1904, 1923-24 (1992) (Scalia, J., concurring in part and in judgment); Payne v. Tennessee, 111 S. Ct. 2597, 2623-25 (1991) (Marshall, J., dissenting).

20. 112 S. Ct. 2791 (1992) (plurality opinion).

21. Thomas v. Washington Gas Light Co., 448 U.S. 261, 272 (1980). 
on the old rule, 22 whether the old rule has proved unworkable, ${ }^{23}$ whether intervening decisions or congressional enactments have rendered the old rule an anachronism, ${ }^{24}$ and whether circumstances have so changed as to eviscerate the justification for the old rule. ${ }^{25}$ Generally mere erroneousness of the old rule is not enough. At least one of the above additional factors is also required. ${ }^{26}$

The traditional approach certainly dominates older stare decisis cases, but it also continues to be used today. The prudential approach is only emerging. Therefore many judges engaging in stare decisis analysis continue to rely on traditional factors only. For example, in the 1993 case U.S. v. Dixon, ${ }^{27}$ Justice Scalia defends the overruling of Grady v. Corbin ${ }^{28}$ on the ground that the rule from Grady was unworkable in practice, confusing, and itself inconsistent with prior decisions of the Court regarding when prosecution for

22. See City of Oklahoma City v. Tuttle, 471 U.S. 808, 818-19 n.5 (1985) (declining to overrule the limitation on municipal liability established in Monell v. New York City Dept. of Social Serv., 436 U.S. 658 (1978), because "decisions on issues such as this are appropriately considered by municipalities in ordering their financial affairs."); Toolson v. New York Yankees, Inc., 346 U.S. 356, 357 (1953) (declining to overrule Federal Baseball Club of Baltimore v. National League of Professional Baseball Clubs, 259 U.S. 200 (1922), because baseball has "been left for thirty years to develop, on the understanding that it was not subject to existing antitrust legislation.").

23. See, e.g., United States v. Dixon, 113 S. Ct. 2849, 2863 (1993) ("Grady is a continuing source of confusion"), overruling Grady v. Corbin, 495 U.S. 508 (1990); United States v. Ross, 456 U.S. 798, 824 (1982) (stating "there was no Court opinion supporting a single rationale for [Robbins]"), overruling Robbins v. California, 453 U.S. 420 (1981); Continental T.V., Inc. v. GTE Sylvania Inc., 433 U.S. 36, $47-49$ (1977) (holding that Schwinn itself was inconsistent with prior doctrine when it was decided and continuing controversy suggests that the old rule is unworkable), overruling United States v. Arnold, Schwinn \& Co., 388 U.S. 365 (1967); Swift v. Wickham, 382 U.S. 111, 126-27 (1965) (holding that Congress intended to confine three-judge requirement to injunction suits depending directly on substantive provision of Constitution supported by all Court precedents until Kesler and by sound policy), overruling Kesler v. Department of Pub. Safety, 369 U.S. 153 (1962).

24. See Harmelin v. Michigan, 501 U.S. 957, 965 (1991) (holding that Weems was erroneous, recent and "in apparent tension with other decisions."), overruling Weems v. United States, 217 U.S. 349 (1910); Arkansas Elec. Co-op. Corp. v. Arkansas Pub. Ser. Comm'n, 461 U.S. 375, 391 (1983) (holding that "[t] $\mathrm{t}$ he difficulty of harmonizing Attleboro with modern Commerce Clause doctrine has been apparent for a long time...."), overruling Public Utilities Comm'n of R.I. v. Attleboro Steam \& Elec. Co., 273 U.S. 83 (1927); Machinists v. Wisconsin Emp. Rel. Comm'n, 427 U.S. 132, 154 (1976) (holding that the so-called Briggs-Stratton case is an anachronism because "[i]ts authority 'has been so restricted by our later decisions'...that [it] must be regarded as having 'been worn away by the erosion of time'... and of contrary authority"), citing United States v. Raines, 362 U. S. 17, 26 (1960), overruling Automobile Workers v. Wisconsin Emp. Rel. Bd., 336 U.S. 245 (1949); Boys Markets, Inc. v. Retail Clerk's Union, 398 U.S. 235, 241 (1970) (holding that Sinclair "frustrates realization of an important goal of our national labor policy"), overruling Sinclair Refining Co. v. Atkinson, 370 U.S. 195 (1962).

25. See Burnet v. Coronado Oil \& Gas Co., 285 U.S. 393, 412 (1932) (Brandeis, J., dissenting).

26. See Michael J. Gerhardt, The Pressure of Precedent: A Critique of the Conservative Approaches to Stare Decisis in Abortion Cases, 10 CONST. COMMENTARY 67 (1993) (arguing that the authentically conservative approach to stare decisis requires more than mere erroneousness to justify overruling, and criticizing the approach of Justices Scalia, Rehnquist and Thomas as too willing to overrule on erroneousness alone). For an example of the view that erroneousness alone suffices to justify overruling in constitutional cases, see South Carolina v. Gathers, 490 U.S. 805, 824-25 (1989) (Scalia, J., dissenting).

27. 113 S. Ct. 2849,2864 (1993).

28. 495 U.S. 508 (1990). 
two offenses will be barred by the double jeopardy prohibition of the Constitution.29

Attention to appearance concerns is absent from the traditional conception. The justices do not worry about whether a decision to overrule will be understandable or acceptable to the public as a principled decision. The only reference to appearance concerns in these traditional cases can be found in dissents. Justices dissenting in these traditional cases sometimes decry the unfortunate effect on the Court's image that the majority's decision is likely to have. ${ }^{30}$ The traditional approach thus is punctuated by dissenting opinions that call attention to negative effects on the Court's image. These justices complain that the majority's (mis)application of the stare decisis doctrine will erode the public's faith in the principled character of the Court's decision-making. Rather than arguing that the Court ought to count the effect on appearance as a factor to be weighed in stare decisis (as later justices will argue), the dissenters in these cases claim that the majority has misapplied the doctrine's traditional elements, leaving the unfortunate impression that the decision (usually a decision to overrule) was motivated by "political considerations" rather than derived from "principled analysis." 31

For example, Justice Stewart, dissenting in the 1974 case Mitchell $v$. W.T. Grant Co.,32 complains that the majority's failure to follow Fuentes v. Shevin $^{33}$ without proper justification will have serious consequences:

A basic change in the law upon a ground no firmer than a change in our membership invites the popular misconception that this institution is little different from the two political branches of Government. No misconception could do more lasting injury to this Court and to the system of law which it is our abiding mission to serve. ${ }^{34}$

29. Dixon, 113 S. Ct. at 2864.

30. See, e.g., Patterson v. McLean Credit Union, 485 U.S. 617, 622 (1988) (Stevens, J., dissenting from the decision to hear argument about reconsideration of Runyon v. McCrary, 427 U.S. 160 (1976)) (deploring what he sees as the likely effect of this request for reconsideration: "the order must also have a detrimental and enduring impact on the public's perception of the Court as an impartial adjudicator...."); Solorio v. United States, 483 U.S. 435, 466 (1987) (Marshall, J., dissenting); Garcia v. San Antonio Metro. Transit Auth., 469 U.S. 528, 559 (1985) (Powell, J., dissenting) (arguing that "[t]he stability of judicial decision, and with it respect for the authority of this Court, are not served by the precipitate overruling of multiple precedents that we witness in these cases."); Oregon ex. rel. State Land Bd. v. Corvallis Sand \& Gravel Co., 429 U.S. 363, 394 (1977); Mitchell v. W. T. Grant Co., 416 U.S. 600, 636 (1974) (Stewart, J., dissenting); Sea-Land Services, Inc. v. Gaudet, 414 U.S. 573, 612 (1974); Furman v. Georgia, 408 U.S. 238, 400 (1972) (Burger, C.J., dissenting) (expressing concern about the Court's vacillation on 8th Amendment issues, comments that "[t]his pattern of decisionmaking will do little to inspire confidence in the stability of the law."); Williams v. Florida, 399 U.S. 78, 129 (1970) (Harlan, J., dissenting); Mapp v. Ohio, 367 U.S. 643,677 (1961) (Harlan, J., dissenting) (complaining that "what has been done [today] is not likely to promote respect either for the Court's adjudicatory process or for the stability of its decisions.").

31. I use these terms loosely here to refer to conceptions of proper (principled) decisionmaking and improper (political) decision-making because this is how these terms are often used in judicial opinions.

32. 416 U.S. 600 (1974) (holding that Louisiana procedure allowing for sequestration of goods in ex parte hearing did not violate due process requirements and did not implicate Fuentes v. Shevin, 407 U.S. 67 (1972), as in that case the debtor was given no notice as well as no opportunity to be heard before seizure of the goods took place).

33. 407 U. S. 67 (1972).

34. Mitchell, 416 U.S. at 636 (Stewart, J., dissenting). 
For the dissenter, the effect on appearance is not a factor to be incorporated into the analysis; rather, it is noted as a hapless consequence of the majority's misapplication (deliberate or unintentional) of the traditional factors. However, the cumulative effect of these dissents may itself work to erode confidence in the Court. This is because the dissenters do more than claim that the majority opinion was not rightly decided (an honest mistake, if you will). Instead, many of the dissenters accuse the majority of not deciding in a principled manner.

Justices employing this traditional stare decisis analysis, in opinions for the Court and in dissent, may not be unconcerned about the effects of overruling on the public perception of the Court. Rather, these justices may believe that by deciding in a principled manner, consistently and conscientiously, they will succeed in protecting the image of the Court as a principle-guided institution. For these justices, the correct deployment of the doctrine of stare decisis will turn out in fact to enhance the esteem in which the Court is held. But this result is not directly sought. In this sense, the traditional cases display a confidence in both the Court's ability to carry on principled judicial decision-making and the audience's ability to recognize it as such.

The lamentful dissents express a similar confidence in the ability of the Court to carry out principled decision-making in a way that is recognizable to its audience. ${ }^{35}$ While the dissenters express some lack of faith in the principled character of the particular majority's decision, their opinions express confidence, as the majority's do, in the public's ability to discriminate between the two. ${ }^{36}$ The traditional conception of stare decisis is thus characterized by the faith that the justices express in the clarity of their reasoning. The principled and the un-principled decision are thought to be easily distinguishable.

\section{The Prudential Conception}

The prudential conception of stare decisis is characterized by a loss of this faith. Because the justices are no longer confident that the principled decision's principled character will be apparent, it becomes necessary to attend to appearance directly. ${ }^{37}$ Consideration of the likely effect of a decision on the

35. See part II.A.1 infra for a discussion of the manifest quality of principled decision-

36. The very fact that these dissenters point out the majority's misapplication of stare decisis doctrine demonstrates a confidence in the distinguishability of the principled and unprincipled application of that doctrine. And, perhaps more importantly, it demonstrates a confidence in their own ability to show the reader which is which.

37. But why have the Justices lost faith in their principled actions being accepted as such? Richard Posner offers some interesting thoughts about this phenomenon. See RICHARD POSNER, THE PROBLEMS OF JURISPRUDENCE (1990). In discussing our general loss of faith in the law's autonomy and objectivity since the 1950s, Posner offers insight into why the Justices may have also lost faith in the public's faith in them. First, the legal profession - and thus judges as well-is made up of an increasingly diverse group of people. This diversity has several dimensions. There is an increase in racial, gender and class diversity and also (and perhaps connected to it) an increase in the diversity of political and moral views endorsed by lawyers and judges. Posner accounts for the increased moral and political diversity of legal practitioners in part as the effect of the burgeoning moral heterogeneity of the country as a whole. Thus "It]he nation's legal heterogeneity mirrors its moral heterogeneity." Id. at 129.

In addition to a growing diversity among judges, Posner cites the increase in litigation generally and the growth in statutory and constitutional law (versus common law) as among the causes of the decline in consensus about legal answers. Id. at 128. Because statutory and constitutional law have expanded into politically sensitive areas, the heterogeneity of judges 
public perception of the Court is thus explicitly recognized as part of the rationale for the doctrine and as a factor to be considered in the application of the doctrine.

The clearest and most explicit statement of the prudential conception of stare decisis is found in the plurality opinion of the 1992 abortion case Planned Parenthood v. Casey. ${ }^{38}$ In the view of the Casey plurality, "not every conscientious claim of principled justification will be accepted as such" and, therefore, "the Court must take care to speak and act in ways that allow people to accept its decisions on the terms that the Court claims for them, as grounded truly in principle, not as compromises with social and political pressures...." 39 Because the principled decision may not be seen as principled, the Court, in deciding whether to overrule, must take into account what effect a particular decision (or reason for a decision) will have on the public perception of the Court.

Interestingly, the Casey plurality employs, and rejects as inadequate, the traditional stare decisis analysis. ${ }^{40}$ An analysis of the traditional factors is not enough in cases, like Casey, where an important and socially divisive issue is under consideration. ${ }^{41}$ In Casey, the Court heard a challenge to a Pennsylvania law regulating abortion. The case, which required the Court to elaborate and refine its growing case law on what constitutes a permissible burden on, or interference with, a woman's constitutionally protected right to an early-term abortion, was widely seen as an opportunity for the Court to re-examine and overrule Roe $v$. Wade. ${ }^{42}$ The plurality opinion (jointly written by Justices O'Connor, Kennedy and Souter) upholds what the plurality terms the "central part" of the holding of Roe on stare decisis grounds. ${ }^{43}$ The section which deals with this stare decisis analysis is broken into two parts, "normal" stare decisis analysis 44 and a more souped-up version for hot social issues. ${ }^{45}$ In the "normal"

leads to a plethora of responses to legal questions. Id. at 128-29. Though different legal thinkers in earlier times may have reached different results in the same case, today this phenomenon is both increasingly likely and the range of answers given increasingly likely to be broad (mirroring the breadth in the array of political and moral views). This fact, that the same question will yield widely divergent legal answers from different figures, for Posner, exposes the "contingency of legal doctrine." Id. at 458.

Even if we lop off the extremes, a broad middle area remains, running from, say, Ronald Dworkin and William Brennan on the left to Robert Bork and Antonin Scalia on the right - two pairs of entirely respectable, 'establishment' figures but so distant from each other ideologically that there is little common ground of discourse. We know that if we give a different legal question to two equally distinguished legal thinkers chosen at random, we may well get opposite Id. at 428 . answers.

This can be taken one step further. If different judges can reach wildly different results, each employing the judicial craft well and in good faith, then it is no longer possible, looking only at the result, to distinguish the judge who has employed her craft well and in good faith from the one who has not. More needs to be taken on faith. But more is not being taken on faith.

38. 112 S. Ct. 2791 (1992) (plurality opinion).

39. Id. at 2814.

40. Id. at $2808-12$.

41. Id. at 2812 ("In a less significant case, stare decisis analysis could, and would, stop at the point we have reached.").

42. 410 U. S. 113 (1973).

43. Casey, 112 S. Ct. at 2812.

44. Id. at $2808-12$.

45. Id. at 2812-16. 
stare decisis section, the plurality applies those factors that I have identified as being part of the traditional conception of the doctrine to Roe's protection of a woman's abortion right. The Justices thus analyze whether the old rule of law has "been found unworkable," whether there has been substantial reliance on the old rule, whether subsequent developments have left the old rule a doctrinal anachronism and whether the facts on which the old rule relied have so changed as to render the old rule irrelevant or unjustifiable. ${ }^{46}$ The plurality's conclusion, based on the application of these factors, is that "the stronger argument is for affirming Roe's central holding...."47

The plurality then moves on to consider whether an understanding of stare decisis that is more protective of precedent is required in cases dealing with politically divisive social issues. 48 The Court compares the circumstances surrounding this case to those surrounding cases in which the Court has overruled itself with regard to similarly explosive social issues. The plurality distinguishes the overruling of Lochner $v$. New York ${ }^{49}$ and other Lochner era cases by West Coast Hotel Co. v. Parrish ${ }^{50}$ and of Plessy v. Ferguson ${ }^{51}$ by Brown v. Board of Education 52 by pointing out that not only were the criteria for overruling articulated in the normal stare decisis section fulfilled in those cases, but also that the fulfillment of the criteria was "comprehensible" to the public, in the plurality's view. 53 The overrulings could thus be accepted by "the thoughtful part of the Nation" as the Court's "constitutional duty" and "not merely as the victories of one doctrinal school over another by dint of numbers." 54 The plurality is thus claiming that in cases dealing with controversial issues, the Court must be especially attuned to appearance.

Finally, the plurality explains why this emphasis on appearance is necessary. In the plurality's view, the Court's ability to be effective depends on its image: "The Court's power lies... in its legitimacy, a product of substance and perception that shows itself in the people's acceptance of the Judiciary as fit to determine what the Nation's law means and to declare what it demands." 55 Recognizing a level of public distrust about the principled character of Supreme Court opinions, the plurality argues that the Court must attend to its appearance in order to preserve its ability to be effective. The plurality argues that in order to safeguard the esteem in which the Court is held, the Court must act to

46. Id. at 2809-12.

47. Id. at 2812 .

48. Id. at 2812-14.

49. 198 U.S. $45(1905)$.

50. 300 U.S. 379 (1937).

51. 163 U.S. 537 (1896).

52. 347 U.S. 483 (1954).

53. Casey, $112 \mathrm{~S}$. Ct. at 2813-16.

54. Id. at 2813.

55. Casey, 112 S. Ct. at 2814 (emphasis added). This claim echoes the views of Justice Frankfurter, dissenting in Baker v. Carr, 369 U.S. 186 (1962). Justice Brennan, for the Court, held that a challenge to a state apportionment statute presented a justiciable constitutional issue. Id. at 199-200. Justice Frankfurter there argued that

[t] he Court's authority - possessed of neither the purse nor the sword-ultimately rests on sustained public confidence in its moral sanction. Such feeling must be nourished by the Court's complete detachment, in fact and in appearance, from political entanglements and by abstention from injecting itself into the clash of Id. at 267 . political forces in political settlements. 
preserve its image. It must "take care" to decide in a way that others can be expected to accept as principled. 56

Interestingly, the Casey opinion cites few cases for the proposition that the Court must attend to appearance. However, it does cite two of the lamentful dissents described earlier. ${ }^{57}$ Until recently, the attention to appearance that we see in Casey has been found almost exclusively among the work of legal commentators. ${ }^{58}$ Of course, the concern about how Court action will affect the public image of the Court not only provides a rationale for the stare decisis doctrine, it also provides part of the justification for our legal system's heavy respect for precedent more generally. The systemic commitment to the relative entrenchment of legal rules reflects the judgment that too much change in legal doctrine would erode public confidence in the Court and in the law. .59

Although the Casey opinion is unique with regard to the length and depth with which it considers the role that appearing legitimate plays-and ought to play-in being legitimate, it is not an anomaly. Rather it is the full-blown treatment of a growing disposition among judges to understand the stare decisis doctrine as grounded in part in the importance of maintaining the Court's image and to treat this rationale as a reason for decision. For example, in the 1991 case Payne v. Tennessee, ${ }^{60}$ which overruled both Booth v. Maryland ${ }^{61}$ and South Carolina v. Gathers, 62 the Court's understanding of the rationale for the doctrine included consideration of appearance concerns. ${ }^{63}$ In Payne, which upheld the admissibility of victim impact evidence in the sentencing phase of trial for a capital offense, Justice Rehnquist writing for the Court explained that "[s]tare decisis is the preferred course because it promotes the evenhanded, predictable, and consistent development of legal principles, fosters reliance on judicial decisions, and contributes to the actual and perceived integrity of the judicial process." 64

Both Payne and another 1991 case, Hilton v. South Carolina Public Railways Commission, ${ }^{65}$ borrow language from a 1986 case, Vasquez $v$.

56. Casey, 112 S. Ct. at 2814.

57. Id. (citing Mitchell v. W.T. Grant, 416 U.S. 600, 636 (1974) (Stewart, J., dissenting) and Mapp v. Ohio, 367 U.S. 643, 677 (1961) (Harlan, J., dissenting)).

58. See supra note 16.

59. See generally LON L. FULLER, THE MORALITY OF LAW 33-41, 79-89 (1964); SCHAUER, supra note 8; Larry Alexander, Constrained by Precedent, 63 S. CAL. L. REV. I (1989); Charles Collier, Precedent and Legal Authority: A Critical History, 1988 WIS. L. REV. 771 (1988); Anthony Kronman, Precedent and Tradition, 99 YALE L. J. 1029 (1990); David Lyons, Formal Justice and Judicial Precedent, 38 VAND. L. REV. 495 (1985); Gerald Postema, On the Moral Presence of Our Past, 36 MCGILL L.J. 1153 (1991); Frederick Schauer, Precedent, 39 STAN. L. REV. 571, 589 (1987). But cf. David Luban, Legal Traditionalism, 43 STAN. L. REV. 1035 (1991) (criticizing Kronman's defense of our deference to the past for its own sake).

60. 501 U.S. 808 (1991).

61. 482 U.S. 496 (1987).

62. 490 U.S. 805 (1989).

63. Payne, 501 U.S. at 827-28.

64. Id. at 827 (emphasis added).

65. 502 U.S. 197 (1991). Hilton is a statutory stare decisis case in which the Court declined to overrule Parden v. Terminal Ry. of Ala. Docks Dep't., 377 U.S. 184 (1964), in so far as Parden held that the Federal Employers' Liability Act (FELA) creates a cause of action against state-owned railroads, enforceable in state court. The Hilton Court defends its decision to stand by Parden on the ground that "[a]dherence to precedent promotes stability, predictability, and respect for judicial authority." 502 U.S. at 202 (emphasis added). 
Hillery. ${ }^{66}$ In Vasquez, Justice Marshall explains the importance of the doctrine of stare decisis in the following way: "[t]hat doctrine permits society to presume that bedrock principles are founded in the law rather than in the proclivities of individuals, and thereby contributes to the integrity of our constitutional system of government, both in appearance and in fact." 67 This stress on the importance of appearing to have integrity (and not just having integrity) as fundamental is the hallmark of the prudential approach. ${ }^{68}$

One of the early cases to adopt what I call the prudential conception of stare decisis is especially clear about the role that this understanding of the doctrine is to play in the application of the doctrine. In Justice Harlan's opinion for the Court in Moragne v. States Marine Lines, Inc. ${ }^{69}$ Harlan explains the rationale for the doctrine as providing clear rules to which people can conform their conduct, allowing conservation of judicial resources and as necessary to "maintain[] public faith in the judiciary as a source of impersonal and reasoned judgments."70 The reasons for overruling an earlier case must, according to Harlan, "always be weighed against these factors." 71 Thus, the fact that a decision will detract from the public faith in the judiciary is, according to Harlan, a reason to be factored into every stare decisis analysis. 72

One of best pieces of evidence that there is emerging a new (prudential) conception of stare decisis doctrine is that the employment of this approach has engendered critique. Justice Scalia has recognized and criticized it-first and foremost in Casey. In Casey, Scalia argues that if the Court were to reach a different result because it included appearance concerns in its stare decisis analysis, this would be "frightening."73 Because Justice Scalia's discussion in Casey provides a forceful defense of the position that it is illegitimate for the Court to base decisions (even in part) on its concern with appearances, I will save Scalia's Casey opinion for the analysis section found in Part II.

66. 474 U.S. 254 (1986). This appearance language from Vasquez is also cited with approval in the dissent. See, e.g., Payne, 501 U.S. at 853 (Marshall, J., dissenting) (augmenting the stress on appearance of the Vasquez language by arguing that "this Court can legitimately lay claim to compliance with its directives only if the public understands the Court to be implementing "principles'..."-and then proceeding to cite Vasquez); Webster v. Reproductive Health Servs., 492 U.S. 490, 559 (1989) (Blackmun, J., dissenting); Solorio v. United States, 483 U.S. 435, 466 (1987) (Marshall, J. dissenting). We could term these the "prudential dissents." Just as the lamentful dissents expressed the same faith in the ability of the Court's audience to distinguish between principled and unprincipled decisions as the traditional opinions do, these prudential dissents are like the prudential opinions in having lost this faith.

67. Vasquez, 474 U.S. at 265-66 (emphasis added). See also Allied-Signal, Inc. v. Director, Div. of Taxation, 112 S. Ct. 2251, 2261 (1992) (citing Hilton, citing Vasquez language discussed in text).

68. Language like this is absent from cases employing the traditional approach to stare decisis. See supra part I.B.

69. 398 U.S. 375 (1970) (holding that maritime law provides a cause of action for wrongful death due to a violation of a maritime duty).

70. Id. at 403.

71. Id. This aspect of Justice Harlan's analysis has been cited approvingly in Sea-Land Servs., Inc. v. Gaudet, 414 U.S. 573, 612 (1974) (Powell, J., dissenting) and Williams v. Florida, 399 U.S. 78, 127 (1970) (Harlan, J., dissenting).

72. Justice Stevens's concurring opinion in Florida Dep't of Health \& Rehabilitative Servs. v. Florida Nursing Home Ass'n, 450 U.S. 147, 153-54 (1981), adopts a similar approach.

73. Planned Parenthood v. Casey, 112 S. Ct. 2791, 2883 (1992) (Scalia, J., dissenting). 
Scalia also objects to the Court's new preoccupation with appearance in South Carolina v. Gathers. ${ }^{74}$ In that dissenting opinion, he admits that appearance concerns are important, but claims that the Court can best preserve its image by clearly and simply overruling erroneous precedents. 75 This opinion expresses that faith in the public's ability to recognize principled decision-making that I described as paradigmatic of the traditional conception.76 Scalia recognizes that appearing principled is important for the Court, 77 as do others employing the prudential approach. But, Scalia adopts a clearly different view about what follows from this acknowledgment. Scalia denies that the Court should allow this concern to affect outcomes.

In sum, the prudential approach is characterized by a loss of faith in the ability of the Court's audience to recognize a principled decision as principled. In addition, it is distinguished by the clear and explicit recognition of the importance of maintaining the Court's power and esteem and of the role that stare decisis doctrine plays in achieving this end. These two views together lead the prudential jurist to the belief that the Court ought to act to preserve its image. Put more starkly, the Court ought to take into account in decisionmaking the likely effect of a decision on the public perception of the Court.

\section{Addendum: Webster}

The appearance factor has surfaced outside of the stare decisis context as well. For the sake of both depth and brevity, we have examined this growing phenomenon in stare decisis doctrine only. By way of addendum, consider, briefly, a case decided on other than stare decisis grounds, Webster $v$. Reproductive Health Services. 78 Webster is interesting because the appearance factor is there incorporated by Justice Scalia, currently the most strident critic of the Court's growing disposition to consider appearance concerns.

74. 490 U.S. 805 (1989).

75. There is, at present, another debate going on within stare decisis doctrine. This debate can be loosely described as a debate between those who favor the overruling of all wrongly decided cases and those who believe that having been wrongly decided is not enough to subject an old rule to revision. The view that the Court must find erroneousness plus some other factor is clearly the dominant view, as well as being the most consistent with the commitment to respect precedent. To permit overruling where the overruling court finds only that the prior court's decision is wrong is to accord the prior decision only persuasive force (it is as good as the reasons or arguments that support it) without according it any weight as precedent.

What is interesting about this debate for our purposes is that the adherents of each position defend that position in part by appealing to its ability to preserve and maintain a positive image for the Court. Justice Scalia defends the mere erroneousness approach on these grounds in Gathers, 490 U.S. at 824-25. See also Moragne v. State Marine Lines, Inc., 398 U.S. 375, 405 (1970). Similarly, the importance of requiring more than mere erroneousness is defended by appeal to appearance concerns. See Florida Dep't of Health, 450 U.S. at 153-55 (Stevens, J., concurring); Mitchell v. W.T. Grant Co., 416 U.S. 600, 634-35 (Stewart, J., dissenting). The requirement of the additional factor helps to preserve the image of the Court as principle-guided both because it acts as a barrier against overruling (overruling itself can be destabilizing) and because it provides additional visible evidence of constraint on judicial decision-making.

76. In Gathers, Scalia argues, "I doubt that overruling Booth will so shake the citizenry's faith in the Court. Overrulings of precedent rarely occur without a change in the Court's personnel. The only distinctive feature here is that the overruling would follow not long after the original decision. But that is hardly unprecedented." Gathers, 490 U.S. at 824 (Scalia, J., dissenting).

77. Quill Corp. v. North Dakota ex rel. Heitkamp, 112 S. Ct. 1904, 1923-24 (1992)

(Scalia, J., dissenting).

78. 492 U.S. 490 (1989). 
In Webster, Chief Justice Rehnquist, writing for the Court, upholds several provisions of a Missouri law that relate to the provision of abortion services within the state as consistent with Roe and the post-Roe development of abortion-related cases. 79 Justice Scalia argues, concurring in the judgment, that the Court should in this case deviate from its general rule: never consider a constitutional question more broadly than is necessary. ${ }^{80}$ In Scalia's view, though this rule is supported by adequate justification, it has a "good-cause exception." 81 In fleshing out what constitutes "good cause" in his view, Scalia articulates a rule which incorporates consideration of appearances. Scalia believes the Court ought here to reconsider Roe, though the provisions of Missouri law do not clearly require such reconsideration. He argues that "[a]lone sufficient to justify a broad holding is the fact that our retaining control, through Roe, of what I believe to be, and many of our citizens recognize to be, a political issue, continuously distorts the public perception of the Court." 82 The doctrine he articulates can thus be restated as follows: Don't consider a constitutional question more broadly than is necessary, except where not doing so will seriously detract from the esteem in which the Court is held. The effect on the Court's image has thus become a factor to be considered under this doctrine. ${ }^{83}$

This Part has described an emerging change in stare decisis doctrine from a traditional conception of that doctrine to a prudential conception. While concern about preserving the Court's image has long been recognized by commentators to be a part of the rationale for the doctrine, it generally has not, until recently, been incorporated in judicial opinions. This explicit attention to appearance concerns - that is, consideration of whether the reason given will be viewed by others as acceptable-is a new and growing phenomenon. It is, however, a phenomenon that has an unorthodox feel. The next section examines the question of whether such a consideration is properly a part of a legal doctrine.

\section{Part II: Should the Court Consider Appearance?}

This section addresses the question whether the United States Supreme Court ought to count as a factor in decision-making what effect a decision will have on the perception of the Court. Ought the Court to take care to be seen as deciding in a principled manner? ${ }^{84}$ This section will argue that this is precisely

79. Id. at 519-20.

80. Webster, 492 U.S. at 532-37 (Scalia, J., concurring).

81. Id. at 534 (Scalia, J., concurring).

82. Id. at 535 (Scalia, J., concurring) (emphasis added).

83. Interestingly, the effect on the Court's image has been understood as part of the underlying rationale for the doctrine instructing the Court not to consider a constitutional issue more broadly than necessary. See, e.g., Village of Euclid v. Ambler Realty Co., 272 U.S. 365, 397 (1926) ("In the realm of constitutional law, especially, this Court has perceived the embarrassment which is likely to result from an attempt to formulate rules or decide questions beyond the necessities of the immediate issue."). Justice Scalia's adoption of the appearance factor in Webster thus constitutes a migration of appearance from background rationale for this doctrine to the place of an explicit factor to be used in the analysis under the doctrine-much like the migration of appearance concerns from rationale to doctrine taking place in stare decisis cases.

84. Jurisprudential writers uses the term "principled" in a myriad of ways. For some, "principled" means a decision justified by the right principles, principles that the writer believes can explain and justify the decision at hand. Most theories of constitutional interpretation employ 
what the Court ought to do. The discussion is divided into two parts. Part A addresses whether judges are permitted to take appearance concerns into account and Part B addresses whether, all things considered, judges ought to take appearance concerns into account. The dual aspect of the question is reflected in Justice Scalia's rejection of the plurality's consideration of the appearance factor in Casey. In Scalia's view, "[t]he only principle the Court 'adheres' to...is the principle that the Court must be seen as standing by Roe," which is, for Scalia, "not a principle of law (which is what I thought the Court was talking about), but a principle of Realpolitik-and a wrong one at that."85 In claiming that consideration of appearance is not a principle of law but, instead, a principle of realpolitik, Scalia is speaking to the question of permission. In his view, the proper understanding of legal reasoning precludes consideration of this factor. In claiming that consideration of appearance is, in addition, a wrongheaded principle of realpolitik, Scalia is speaking beyond the permission question to the issue of whether, even if the Court were permitted to consider the appearance factor, it ought, all things considered, to do so. Scalia thinks that on purely practical grounds, this principle is a poor guide for decision.

This first question is posed from the inside. It asks whether the internal norms of legal decision-making permit the Court to take into account appearance concerns. The second question is posed from the outside. It asks whether the norms governing legal decision-making are the right norms; whether the Court ought, from a moral and political point of view, to take care to preserve the esteem in which the institution is held.

One final note. The view that taking appearance into account in judicial decision-making is appropriate is a view with a prudentialist cast. ${ }^{86}$ It is reminiscent of Alexander Bickel, and deliberately so. ${ }^{87}$ Recently there has been a renewed interest in Bickel's prudentialism-a neo-prudentialism. ${ }^{88}$ While this article seems to partake of this recent enthusiasm, it does so only partially and

the term in this manner. See, e.g., JOHN H. ELY, DEMOCRACY AND DISTRUST: A THEORY OF JUDICIAL REVIEW (1980) (proposing that the invalidation of state statutes under one of the openended provisions of the Constitution be judged according to whether there is a defect in the process by which the statute became law).

For others, a sharper distinction can be drawn between what commitments ought to form the basis of principle and the manner in which these "principles" are applied. By principled decision-making, these writers usually mean decision-making guided by the good faith application of whatever principle of decision the judge or jurist actually endorses. See generally STEVEN BURTON, JUDGING IN GOOD FAITH (1992); POSNER, supra note 37. Herbert Weschler's "neutral principles" jurisprudence can best be described as following this second approach. Herbert Wechsler, Toward Neutral Principles of Constitutional Law, 73 HARV. L. REV. 1, 19. See also Kent Greenawalt, The Enduring Significance of Neutral Principles, 78 COLUM. L. REV. 982, 985 (1978) (claiming that by "neutral," Weschler meant a basis for decision which the judge would be willing to apply consistently to relevantly similar cases).

85. Planned Parenthood v. Casey, 112 S. Ct. 2791, 2883 (1992) (Scalia, J., dissenting).

86. Prudentialism emphasizes the importance of accommodating the practical and political constraints on action and decision. The legal thinker most often associated with prudentialism is Alexander Bickel. See infra part II.B.3.

87. Bickel's central contribution was his theory of the "passive virtues" of adjudication. In Bickel's view, the Supreme Court must protect its political viability and be wary of the symbolic power of its actions. He encouraged the Court to let these concerns play a role in the application of the doctrines that govern access to the Court. See ALEXANDER BICKEL, THE LEAST DANGEROUS BRANCH: THE SUPREME COURT AT THE BAR OF POLITICS (1962).

88. See infra part II.B.5. 
hesitantly. With Gerald Gunther and others I find Bickel's advocacy of the covert deployment of prudential values indefensible. ${ }^{89}$ Moreover, I find his traditionalism problematic. What I do take from Bickel is his attempt to mediate between what he describes as principle and expediency, ${ }^{90}$ and others have described as the ideal and the real. .91 However, for me this mediation has a different character than for Bickel. To Bickel, the actual and political worlds are understood as requiring compromises with principle.92 For Bickel, these compromises are legitimate, but lamented-they are the necessary accommodations to an imperfect world. ${ }^{93}$ Bickel writes against those who deny that principled decision-making (rightly understood) can legitimately permit such expedient or politically necessary compromises. ${ }^{94}$ But, both Bickel and those with whom he disagrees hold one view in common: that accommodation of legal decision-making to expediency is compromise.

This article argues against this characterization of the accommodation of legal decision-making to the needs of the actual world. Rather, because part of the judicial role requires the justification of legal outcomes, a good decision is one which succeeds in this respect. Moreover, because Court power is intimately tied to the respect the Court commands, the Court must attend to its image in order to preserve its ability to be effective. This ability to be effective matters normatively as well as practically. As is argued in section B, the Court must be able to compel compliance with its directives generally in order to justifiably compel compliance with its directives in individual cases. The accommodation of legal decision-making to these requirements is not the compromise of principle for the sake of expediency. Rather, it is the incorporation, clearly and explicitly, of a normatively necessary component of legitimate judicial action.

\section{A. Permission}

This section argues that judges are permitted to take appearance concerns into account. This claim is based on the argument that for the Court, as for other repositories of public trust, appearing principled is a necessary component of being legitimate and, thus, appearing to decide in the appropriate manner is a part of what correct decision-making entails. The section addresses and replies to two important objections to this view. First, some might argue that for a judge to take into account the likely effect of a decision on the public perception of the Court is to compromise judicial independence. In this section, I present an account of what the commitment to independence entails. Properly understood, the commitment to judicial independence is not threatened by the requirement that the judge attend to appearance concerns. Second, one might argue that the inclusion of the appearance factor is prohibited because it is not a "legal" consideration but rather involves an illegitimate incursion of "politics," or the non-legal, into law. This objection implicitly depends on either a

89. See Gerald Gunther, The Subtle Vices of the "Passive Virtues"-A Comment on Principle and Expediency in Judicial Review, 64 COLUM. L. REV. 1, 14 (1964).

90. BICKEL, supra note 87, at 64-72, 95-96.

91. Paul Gerwirtz, Remedies and Resistance, 92 YALE L. J. 585, 587 (1983).

92. This aura of compromise pervades Bickel's The Least Dangerous Branch. BICKEL, supra note 87, at 131-32 (discussing the tension between legality and democracy).

93. BICKEL, supra note 87 , at 131-32.

94. This, I take it, is Gunther's view. See Gunther, supra note 89. 
normative theory of adjudication or of constitutional interpretation which would proscribe the consideration of certain kinds of concerns. This section will survey several such theories to see whether, in fact, the inclusion of the appearance factor would be permitted by each. The result of this survey will be that the appearance factor would be permitted by some, but not all, normative theories of adjudication and of constitutional interpretation. This result leaves the appearance factor in much the same place and with much the same status (as properly "legal") as many other factors that are permitted by some, but not all, theories of adjudication.

\section{The General Argument}

A brief digression. Why is there a need to attend to appearance concerns separately? If the judge is concerned about appearing principled, why can she not simply be principled and thus appear so? Unfortunately, the Justices today are not confident of the ability of principled decision-making to command a principled appearance. 95 They have lost faith in what I call the "manifest quality" of principled decision-making. It is because the principled quality of the principled decision is no longer believed to be readily apparent and understandable that the judge must attend to appearance as a discrete element.

An analogy will demonstrate what I mean by the "manifest quality" of principled decision-making and what causes this quality to be lost. Suppose that I want to both dress appropriately for my job as a law professor and I want to appear to be dressing appropriately. To accomplish both goals I simply wear the right clothes. Since what one is wearing is readily discernible, by wearing appropriate clothes I will simultaneously appear to be doing so. In this example, one could say there is a manifest quality to clothes-wearing. This manifestness depends, however, on there being relatively uncontroversial rules governing what are the appropriate clothes for law professing. Suppose I believe that a law professor, to be dressed appropriately, must wear clean clothes that keep her at a comfortable temperature. Suppose I also know that others do not share this view (they think one ought to be dressed up-jacket and tie for men, comparable dress for women). I can no longer simply wear what I believe to be the appropriate clothes in order to also appear so. In order to both be dressed appropriately and also appear so, I may have to wear a skirt and jacket.

The basic idea is this: the fact that there is dispute about what the clothes appropriate to law professing are (or what principled decision-making entails) necessitates attention to the appearance dimension separately. Today, the Justices on the Court seem to think that there is enough dispute about what principled decision-making entails to require independent attention to appearance concerns. Clearly it is not the case that at some past moment (some good old day), there was no dispute about what principled decision-making required. In this sense the principled quality of decision-making has never been truly manifest. However, there is today more dispute about what is required, more diversity and heterogeneity of viewpoints (even among mainstream judges and commentators) about what it means for a judge to decide in a principled

95. See supra part I.C. 
manner. ${ }^{96}$ Therefore, in order to appear principled the judge can no longer simply decide in a manner that she believes to be principled. More is required.

But ought courts to care about deciding in a manner that will be seen as principled? Analogously, ought I to care about dressing in a way that others will perceive as appropriate? In what follows I argue that good judging requires, in part, offering reasons that not only are principled (according to the judge's own conception of what principled decision-making entails) but also that are likely to be accepted as principled by those to whom they are offered.

The reasons offered by a judge for a decision are meant to provide a justification for that decision. Therefore, the reasons offered must provide warrant for the outcome reached. Moreover, in order to justify the decision to the parties affected by that decision and to others, the reasons offered must also be reasons that these others can accept as reasons. We require that courts publicly give reasons not only so that we can constrain the judicial product, 97 nor only so that reviewing courts have a basis for that review, but also to legitimate the outcome reached to those affected by it. In order for a court to do that, it must offer reasons that others can accept as reasonable grounds for decision. Note that this requirement does not entail that the justifying body offer reasons that others view as right. (It would most likely be impossible to do so given the diversity of views out there ${ }^{88}$ - and would be problematic to try as this would subvert the independence of the judiciary. ${ }^{99}$ )

An analogy will help to illustrate why the reasons offered by the judge must appear principled in order to successfully justify a decision. Consider the case of a math teacher who explains the proof of a mathematical theorem correctly but in a manner that is inaccessible to his students. Though the explanation may meet some of the criteria for a good explanation, it clearly has not met them all. Part of what makes a good explanation good lies in the explanation's ability to reach others. At least this is so of an explanation offered by a teacher to his students. A justification offered by a public institution for an action it takes has a similar quality. The context in which this justification is offered generates important constraints on it-as the context of teaching imposes the requirement of accessibility on the teacher's explanation. Just as for a teacher to explain is to offer an account that is likely to make sense to students, for a court to justify is to provide reasons that are likely to be acceptable to members of the court's audience. The teacher must count the fact that a contemplated explanation is likely to be difficult to understand by his students as a reason that weighs against using that explanation. Similarly, the judge ought to count the fact that a decision will not be perceived as principled as a reason to come out differently.

In addition, the judicial role requires that the judge protect the perceived integrity of the Court. ${ }^{100}$ This requirement derives in part from statute. Section

96. For a discussion of why there is more diversity of viewpoints among jurists and what impact this diversity is having in legal opinions, see supra note 37.

97. This may be a very minimal constraint. See, e.g., Duncan Kennedy, Freedom and Constraint in Adjudication: A Critical Phenomenology, 36 J. LEGAL EDUC. 518, 522 (1986).

98. See supra note 37.

99. See infra part II.A.2.

100. An analogy will illustrate why and how this duty functions as a part of the judicial role. Suppose a male college professor has a student in his class who needs and wants as much extra help in the course as the professor is willing to give. The student is motivated and 
455(a) of Title 28 of the United States Code, which governs judicial disqualification and recusal, provides that a judge ought to recuse himself "in any proceeding in which his impartiality might reasonably be questioned."101 Moreover, the ABA Model Code of Judicial Conduct requires that judges avoid creating the appearance of impropriety. 102 In fact, the view that public officials generally have a duty to maintain an appropriate appearance in order to foster the public trust necessary to their role is widely accepted. ${ }^{103}$

interested in the subject area but is having trouble understanding and assimilating the material. Imagine further that the student is an attractive female student. While I apologize for the stereotyping in the example, it is precisely the reactions that such stereotypical situations engender that this hypothetical exploits. (For an interesting examination of the question whether some reactions are illegitimate and thus ought not to be accommodated, see Alan Wertheimer, Jobs, Qualifications, and Preferences, 1983 ETHICs 99.) Assume that the professor is quite committed to helping his students with the course material when the need arises and thus, other things being equal, would be willing to spend a lot of time working with this student. Assume further that he begins working with her in his office on a daily basis. Because he does not want to compromise other students' access to him, whenever another student comes by the professor's office, the professor will interrupt his work with our student and turn to the new student. After several weeks of this, the professor begins to notice the odd glances other students in the class give upon seeing the professor with our student, again. The professor begins to wonder whether other students are forming the impression (wrongly) that some sexual or romantic relationship is going on between himself and our student.

The professor thus engages in the following decision-making process. He counts the fact that other students will think (wrongly) that he is having an affair with one student as a reason not to meet with that student individually so often. This does not mean that he necessarily will stop meeting with our student in his office. He may decide that, all things considered, the importance of working individually with her outweighs the harm done by giving the rest of the students the false impression that he is having an affair with one student. Or, he may come to believe that he can counter the mistaken impression given by his meetings with our student in some other manner. What is important for us here is that he rightly counts the fact that others will misperceive his actions as a reason that influences how he decides to act.

101. 28 U.S.C. § 455(a) (1948). Interestingly, a recent Supreme Court case interpreting this statute reproduces the debate about the role of appearance. See Liteky v. U.S., 114 S. Ct. 1147 (1994). In Liteky, the Court, unanimous in its judgment that the judge-in-question's conduct in a particular case did not require him to recuse himself, debated the applicability of what is known as the "extra-judicial source rule." That rule provides that in order to find bias or the appearance of bias requiring recusal, the source of such alleged bias must originate outside of the proceedings. Justice Scalia, writing for the Court, held that while the rule is not dispositive (in Liteky the source of the alleged bias was from within the proceedings themselves), it is a factor to be accorded significant weight. Thus, the applicability of the rule can only be avoided where the intra-judicial source of bias makes it impossible to get a fair judgment. Justice Kennedy, concurring in the judgment, rightly points out that Scalia has eviscerated part (a) of the statute. What matters, according to Kennedy, is not only the fact that one can not actually get a fair hearing, but also that it may appear, to the reasonable person, that one can not get such fairness. As Justice Kennedy explains, "[i]n matters of ethics, appearance and reality often converge as one." Id. at 1162.

102. MODEL CODE OF PROFESSIONAL RESPONSIBILITY Canon 9 (1980), instructs that "A Lawyer Should Avoid Even the Appearance of Professional Impropriety"; MODEL CODE OF JUDICIAL CONDUCT Canon 2 (1980), instructs that "A Judge Shall Avoid Impropriety and the Appearance of Impropriety in All of the Judge's Activities."

103. The claim that appearances matter ethically as well as politically for the legislator is made convincingly by Dennis Thompson. See DENNIS THOMPSON, ETHICS IN CONGRESS 124 (1995) (arguing that as "the price of trust in a democracy, [public officials must] not give reason to doubt their trustworthiness" and thus that public officials have a moral obligation to avoid creating compromising appearances). See also Julia Driver, Caesar's Wife: On the Moral Significance of Appearing Good, J. PHIL., Vol. LXXXIX, No. 7, at 338 (1992) (explaining that "whenever we are in a situation where our actions can be...misconstrued, we must be careful, because what we do may set an example for others."); Andrew Stark, The Appearance of Official Impropriety and the Concept of Political Crime, 105 ETHICS 326 (1995) (exploring the tension between the prohibition against the appearance of official impropriety and norms of 
I take the above two claims to be fairly uncontroversial. Most would agree that the better justification is one which is perceived by those to whom it is addressed as providing warrant for the decision reached. Similarly, most would agree that a judge ought to avoid acting in a way that is likely to compromise the perceived integrity of the judiciary. There is likely to be disagreement, however, about whether this appearance requirement ought to be balanced against other criteria of proper judicial decision-making. For example, it could be the case that while it would be good if a decision were perceived as principled, the court can not take this concern into account in decision-making without compromising judicial independence. Alternatively, it could be the case that by taking this appearance concern into account, the court decides improperly and thus lacks warrant for its decision. It is to these two objections to the inclusion of the appearance factor in legal decision-making that we now turn.

\section{The Commitment to Judicial Independence}

This section addresses an anticipated objection. One might argue that while maintaining the image of the Court as a principle-guided institution is important, the attempt to achieve this good cannot be conceived of as an aspect of the judicial role (as is argued above) because the act of attending to appearance compromises judicial independence. The idea is this: judicial independence requires that judges decide cases without regard to the public's view about the subject matter involved. It is for this reason that federal judges enjoy life tenure. 104 In order to insure that we have a government of laws rather than of men, judges must decide cases on the basis of the designated "legal" material only-and not by consulting public opinion or sentiment. However, in asking judges to be responsive to the acceptability of the reasons they offer for their decisions (as the appearance factor would do), we ask judges to compromise this independence.

In order to examine this objection, we need a clear idea of what judicial independence is and what it requires. In what follows, I offer an account of judicial independence. Based on this analysis of what the commitment to judicial independence entails, I will show that consideration of the appearance factor by judges does not compromise judicial independence, properly understood.

The claim that the judiciary ought to be independent is a claim about the kinds of reasons that judges ought to rely on in reaching decisions. For example, in the case of a judge deciding whether a state statute regulating access to abortion is in conflict with the Constitution, independence requires that the judge only consider certain kinds of reasons. The judge may consider whether there is support for the abortion right in the constitutional text, the history of certain textual provisions, the previous decisions of the Unites States Supreme Court relating to the right, or whether the right to abort is a fundamental aspect of liberty, etc. This list is clearly not exhaustive, nor is it uncontroversial. Different theories of constitutional interpretation license the consideration of

legal justice, specifically the norm against prejudgment of the facts of a case and the norm against retroactive law).

104. See U.S. CONST. art. III, $\S 1$ ("The Judges, both of the supreme and inferior Courts, shall hold their Offices during good Behavior[.]"); THE FEDERALIST No. 78 (Alexander Hamilton). 
different factors. ${ }^{105}$ What these factors share is that each purports to bear directly on the issue under consideration, i.e. whether the statute is constitutional. For example, to the judge who endorses a textualist approach ${ }^{106}$ to constitutional interpretation, the fact that there is or is not support for the abortion right in the constitutional text is directly relevant to the determination of the statute's constitutionality. Let's call such a factor, which purports to bear directly on the subject under decision, a "first order reason." 107

The thesis being offered is that independence requires that judges decide cases according to first order reasons only. What kinds of reasons does this commitment prohibit? A judge is not permitted to count the fact that the public thinks that the abortion right is protected by the Constitution as a reason on which her decision is based. This factor (what the public thinks) does not purport to bear directly on the constitutionality of the statute; rather, it offers someone else's view about the constitutionality of the statute. The inclusion of this reason would compromise judicial independence because it would involve the transference of some decision-making power from the judge to the public.

Consider an analogy. Imagine that I am grading an exam. Based on my view about what is required for a good answer to the exam question posed, I develop a list of factors that count as reasons to give the exam a particular grade. For example, my list could include the following factors: discusses issue $\mathrm{X}$; discusses issue $\mathrm{Y}$; discusses issue $\mathrm{Z}$; is complex; is well-written. Each of these factors purports to bear directly on what grade the exam ought to receive (based on my theory about what a good exam answer requires). Thus, each factor provides a first order reason to assign a particular grade to the exam. If, based on these factors, I give the exam a B, the "B" sums up my evaluation based on these factors. If the course grade is based, in whole or in part, on the student's performance on the exam, then this B provides a first order reason to give the student a B in the course. Joseph Raz calls this kind of reason a "dependent reason" because it depends on-stands in for-other reasons. 108 Here the exam grade of B stands in for the fact that the student's exam was moderately complex, discussed issues $\mathrm{X}$ and $\mathrm{Y}$ but not $\mathrm{Z}$, etc.

Now, consider what happens when I include among the reasons on which I rely in determining the exam grade the fact that the student believes that the exam deserves an A. The student's assignment of " $\mathrm{A}$ " to her exam is meant to depend on a list of first order reasons too (though perhaps a different list than my own). She considers factors that she believes bear directly on what grade the exam ought to receive. Based on those factors (which she considers to be first order reasons), she assigns an A to her exam. If I include among the first order reasons that I consider the fact that the student thinks the exam deserves an A, I would be including among my list of first order reasons a factor that

105. See infra part II.A.3.b.

106. For a discussion of textualism, see infra part II.A.3.a.vi.

107. I adopt this terminology from Joseph Raz. His discussion of various categories of reasons is helpful to sorting out what the commitment to judicial independence entails. Raz offers a general account of the nature of various types of reasons and their interrelation. Therefore, my adoption of his terminology should in no way be taken to imply that Raz would endorse my analysis of judicial independence. See JOSEPH RAZ, PRACTICAL REASON AND NORMS 36-39 (1975).

108. JOSEPH RAZ, THE MORALITY OF FREEDOM 41 (1986). Note that in this example, "student got a B on exam" is both a dependent reason and itself a first order reason to give the student a B in the class. 
itself is the evaluative conclusion of someone else. It is a dependent reason which stands in for first order reasons that, according to someone else's theory of grading, bear directly on what grade the exam ought to get. If I include this dependent reason among the first order reasons that I consider in assigning a grade to the exam, I will transfer some evaluative power to the student, in that her determination of what are the appropriate first order reasons to consider in this context becomes relevant. Perhaps in exam grading that would be a good thing. What it is important for us to note is that by including a dependent reason among first order reasons, the primary decision maker transfers some decision-making authority to some other source.

My claim is not that there is something wrong in general with including dependent reasons among first order reasons in all cases. Rather, I am claiming that it is precisely this kind of transfer of judgment that the commitment to judicial independence proscribes. Judicial independence requires that the judge exclude dependent reasons from her list of first order reasons for decision in the cases before her. The judge's method of adjudication can not include reliance on another's judgment.

If this is the right analysis of what independence requires, then consideration of appearance will not threaten judicial independence. The fact that a reason or a decision will look unprincipled is not a dependent reason. It does not sum up someone else's evaluation-it is not based on first order reasons of someone else's choosing. Rather, looking unprincipled is a feature of the decision itself and, as such, better described as a first order reason of the ordinary kind. Just as I might count the fact that an exam paper is persuasive as a reason to assign it a good grade, I count the fact that a decision would appear principled as a reason on which the final determination is based.

Of course, both "being persuasive" and "appearing principled" do require attention to the reaction or probable reaction of others, and in this way may seem to threaten judicial independence. However, independence does not prohibit acknowledging the views of others. In fact several constitutional doctrines incorporate public reaction to events in determinations of constitutionality in just this sort of way. For example, in order to determine whether a holiday display violates the Establishment Clause, we must look at whether the display is likely to be seen as an official endorsement of a sectarian creed. ${ }^{109}$ The requirement that a decision or a reason for a decision appear principled can be seen as analogous to the requirement that an essay be persuasive. 110 The inclusion of this factor takes account of whether the

109. See, e.g., County of Allegheny v. ACLU, Greater Pittsburgh Chapter, 492 U.S. 573, 594-97 (1989) (holding that when determining whether a holiday display violates the Establishment Clause, the Court must "ascertain whether 'the challenged governmental action is sufficiently likely to be perceived by adherents of the controlling denominations as an endorsement, and by the nonadherents as a disapproval, of their individual religious choices"” (quoting School Dist. of Grand Rapids v. Ball, 473 U.S. 373, 390 (1985))) (emphasis added).

110. John Rawls's conception of "public reason" imposes similar constraints on those who would exercise coercive power over others in a political community. In answer to the question, "in light of what principles and ideals must we exercise that [coercive political] power if our doing so is to be justifiable to others as free and equal," Rawls provides the following account: "our exercise of political power is proper and hence justifiable only when it is exercised in accordance with a constitution the essentials of which all citizens may reasonably be expected to endorse in the light of principles and ideals acceptable to them as reasonable and rational." 
justificatory function of the court will be fulfilled in the particular case-and in this way it is cooperative and interactive. But, the inclusion of the appearance factor does not transfer decision-making authority and thus does not conflict with the commitment to judicial decision-making independence.

In sum, the commitment to judicial independence prohibits the inclusion of reasons that defer judgment. But, this "evil" is not present in judicial consideration of whether a reason or decision will be perceived as principled. Rather, the inclusion of the appearance factor simply expresses respect for the pluralism of views about the right way to reach legal results by requiring that the reasons offered by judges be reasons that are likely to be accepted by others as principled reasons. In this way, inclusion of the appearance factor helps judges to succeed in justifying their decisions to others.

\section{Not a "Legal" Consideration}

The Court's power depends, at least in part, on the esteem in which the Court is held. Therefore, we can recharacterize the question of whether the Court ought to be concerned about its image as follows: Ought the Court to be concerned about its continued ability to be effective over time? Earlier we mentioned that some critics of the inclusion of the appearance factor claim that its inclusion is barred by the proper understanding of judicial decision-making. By paying attention to appearance concerns, these critics argue, a court will reach a decision that looks warranted but is not. Similarly, were a court to base a decision, in part, on that decision's likely effect on the Court's ability to be effective, this decision would cease to be a properly legal decision, according to this view. It is to this objection that we now turn.

\section{a. Permitted by Some Normative Theories of Adjudication}

In order to know whether the Court may consider the likely effect of a decision on the Court's ability to be effective over time (the effectiveness factor), we must first note two facts about our legal landscape. First, there is a wide-ranging debate in academic circles and on the Court today about what adjudication in general, and constitutional interpretation in particular, require. ${ }^{111}$ Second, there is no end in sight to this debate.112 However, in order to answer the question posed in this section, precisely what one needs is a normative theory of adjudication.113 In order to know whether the concern about the effect on effectiveness is, properly, a "legal" concern or not, one needs a way of separating the legal from the non-legal. But this is precisely what we lack. We do not have $a$ theory of what considerations judges may properly consider; instead we have several theories of what adjudication requires.

JOHN RAWLS, POLITICAL LIBERALISM 217 (1993). For Rawls, acceptability to other reasonable people thus provides the basis of political legitimacy. Id.

111. It would be cumbersome and ultimately unhelpful to cite evidence of this debate. Here I appeal instead to the reader's sense of the contemporary legal and academic scenes.

112. There is no end in sight because there are no agreed upon criteria for determining which among competing conceptions of the right way to decide cases (or constitutional cases) is best.

113. A "normative theory of adjudication" is a theory which describes the manner in which judges ought to decide cases and articulates criteria for the reasons or types of reasons the judge may consider. 
Without endorsing or defending a particular, contestable normative theory of adjudication or of constitutional interpretation ${ }^{114}$ (tasks beyond the scope of this article), what can be said? From the standpoint outside of any particular theory, we can say that consideration of the effectiveness factor is permitted by some theories and prohibited by others. In what follows I will briefly sketch how three normative theories of adjudication and three theories of constitutional interpretation would treat consideration of the effectiveness factor. I will ask about each whether it would permit consideration of this factor.

General normative theories of adjudication will be examined first. These are divided into three categories: those for which the distinction between the legal and the non-legal is no longer very meaningful, 115 those for which this separation remains robust, ${ }^{116}$ and hybrid theories in which there is a weakly maintained distinction between the legal and the political or moral realms.117 This distinction between the legal and the non-legal is often referred to as the "law-politics distinction" where "law" denotes that on which the judge ought to base her decision and "politics" denotes that on which she is not permitted to rely. "Politics" here is clearly being used broadly. The point for us is that some normative theories of adjudication adhere to the claim that the judge may only base a decision on certain kinds of reasons described as legal reasons (for example, the legislative history of a statute). By contrast, other theories deny that reasons can be neatly separated, or separated at all, into legal and non-legal categories. For the remainder of this article, I will use the terms "law" and "politics" as they are ordinarily used to denote the "legal" and "non-legal" categories of reasons.

\section{i. Critical Legal Studies and Law and Economics}

"Critical Legal Studies" and "Law and Economics" are each descriptive labels that are applied to the views of a somewhat diverse group of "adherents." In what follows, I will appeal only to those views that I believe are widely shared by that group and/or are generally associated with it. One of the basic tenets of Critical Legal Studies ("CLS") is that "law and society are inseparable and interpenetrating." 118 Moving beyond the Legal Realist insight that the norms of law are underdeterminate, CLSers emphasize the structured conflicts that pervade and permeate both legal materials (statutes, precedents, the Constitution) and "background" political and moral views. ${ }^{119}$ For the CLSer, therefore, no considerations are proscribed a priori. CLS instructs the judge to examine what can be accomplished, practically speaking, in a given decision.120 While the CLS judge may not, all things considered, finally endorse consideration of the effectiveness factor, because CLS explicitly rejects a potent

114. A "normative theory of constitutional interpretation" is a theory that provides a justificatory account of the judicial role in reviewing legislative pronouncements and articulates criteria for the reasons or types of reasons that judges may consider in deciding constitutional cases.

115. See infra part II.A.3.a.i.

116. See infra part II.A.3.a.ii.

117. See infra part II.A.3.a.iii.

118. MARK KELMAN, A GUIDE TO CRITICAL LEGAL STUDIES 7 (1987).

119. See, e.g., Duncan Kennedy's discussion of individualism and altruism in Duncan Kennedy, Form and Substance in Private Law Adjudication, 89 HARV. L. REV. 1685 (1976).

120. See generally Kennedy, supra note 97. 
law-politics distinction, it lacks the theoretical tools to proscribe certain considerations at the outset as non-legal in character. Therefore, CLS, understood as a normative theory of adjudication, will permit consideration by judges of the effectiveness factor.

Law and Economics ("L\&E") is similar to CLS in that it too lacks the theoretical tools to separate the legal and the non-legal consideration. As L\&E is most commonly employed in the common law context, it may seem inappropriate to consider what $L \& E$, viewed as a general normative theory of adjudication, would say about the inclusion of the effectiveness factor. I think it is helpful to take this approach, however, in order to get a general sense of how this influential theory would treat the effectiveness factor-looking at both in the abstract.

To the L\&E adherent, the law both is and ought to be guided by considerations of wealth maximization. ${ }^{121}$ As this is the dominant normative criterion guiding adjudication, $L \& E$ would also not prohibit consideration of the effectiveness factor, at the outset. Whether $L \& E$ would endorse its inclusion in particular cases would depend on whether doing so would be efficient in fact in that case. This determination would depend on the answer to such questions as whether consideration of the effectiveness factor is likely to achieve its end (preserving the prestige and power of the Court) and if and how much a diminution in the Court's effectiveness would lead to a similar diminution in overall social utility (generally measured by wealth). Because wealth maximization ought to guide judicial decision-making, according to $L \& E$, all considerations that are candidates for inclusion in legal decisions are evaluated by this criterion-predominantly. Therefore, L\&E would permit consideration of the effectiveness factor-and would endorse its inclusion in legal decisionmaking -if doing so would increase social utility (or wealth).

\section{ii. Theories That Maintain a Robust Law-Politics Distinction}

Theories that maintain a robust distinction between law and politics characterize legal decision-making as authorized by a limited number of sources, for example, by statutes and the Constitution only. The judge, according to such theories, is not permitted to import considerations drawn from other sources into law. Doing so is described pejoratively as the usurpation of power from the democratic branches of government by the unelected judiciary. Into which category would the effectiveness factor fit, the legal or the non-legal? One could argue that the effectiveness factor may be incorporated into judicial decision-making if it is already present in other legal doctrines or sources. If it is present in these doctrines, perhaps it is, properly, a legal concern. Concern about effectiveness and about appearance are both already present in law. ${ }^{122}$ Therefore, perhaps we can conclude that the Court may consider them.

121. See generally POSNER, supra note 37, at 353-92. In a chapter on L\&E, Posner describes its commitments as follows:

Since wealth maximization is not only a guide in fact to common law judging but also a genuine social value and the only one judges are in a good position to promote, it provides not only the key to an accurate description of what the judges Id. at 360-61. are up to but also the right benchmark for criticism and reform.

122. See supra part I. 
The above approach may not be satisfying to some adherents of a legal theory with a potent law-politics distinction because the effectiveness factor may have been erroneously incorporated by earlier judges. This critic wants to claim that consideration of the effect of decision-making on the Court's continued effectiveness is inherently not a legal kind of consideration. This critic is not simply claiming that as a matter of fact the incorporation of effectiveness into law at an earlier moment was unwarranted at the time, but instead that the incorporation of this factor could never have been warranted and thus its improper inclusion provides no grounds for its continued use. On what does this claim rest? Where a factor has been candidly employed in decision-making, is present elsewhere in law, and responds to a need of the community (effective judicial action), the burden shifts to those who would claim that such a factor can not be a legal concern to articulate why this is so.

\section{iii. Hybrid Theories}

Ronald Dworkin offers what I call a hybrid theory.123 In Dworkin's account there is a meaningful distinction between the law's politics (or, the law's morality) and real politics (or, morality). ${ }^{124}$ However, in determining what the law's politics or morality is, a judge must appeal to a background political or moral theory (meaning one that is not strictly or fully a part of law). ${ }^{125}$ In this sense, Dworkin's theory maintains a soft distinction between the legal and the non-legal.

Dworkin's theory of adjudication, "law as integrity", which is both descriptive and normative in character, requires that principles, in order to qualify as legal principles, both fit with other available legal doctrine and provide a good justification for that body of doctrine.126 The "fit" requirement insures that the principle adopted will be a principle of our law while the "justification" requirement allows the importation of a background political or moral theory into law in order for the judge to decide which among the competing principles that fit reasonably well provides the best understanding of the specific doctrinal area. ${ }^{127}$ Rather than simply asking for the closest fit, Dworkin claims that legal reasoning, properly understood, requires the judge to choose the principle or reason that both fits and justifies existing law. ${ }^{128}$ Because the appeal to justification requires an appeal to a background political or moral view (in order to determine which among the decisions that fit also justifies), this view permits the consideration of what effect a decision will have on the Court's ability to be effective over time. Were a particular reason or decision (which admittedly fit available legal doctrine) to erode the public confidence in the Court and thus diminish the Court's ability to be effective, it would likely fail the justificatory prong of the analysis. So long as a loss in the Court's ability to be effective is viewed negatively, this reason or decision, though it fit, may not be the best choice available to the judge.

123. See RONALD DWORKIN, LAW'S EMPIRE (1986).

124. Id. at 219.

125. Id. at 255-58.

126. Dworkin explains, "[a]ccording to law as integrity, propositions of law are true if they figure in or follow from the principles of justice, fairness, and procedural due process that provide the best constructive interpretation of the community's legal practice." Id. at 225.

127. Id. at 239. 
Any normative theory of adjudication that includes such a "justification requirement" would thus allow the consideration of the effectiveness factor. In order to decide which reason or principle best justifies an area of law, one must appeal to a political or moral theory that one holds for other reasons. If this political or moral theory includes the view that it is important for the Court to continue to be effective over time, then this theory of adjudication would support the use of the effect on effectiveness factor within legal analysis.

\section{iv. Prudential Theories}

We turn now to theories of constitutional interpretation to see how such theories would treat inclusion of the effectiveness factor in cases posing constitutional issues. We are thus moving slightly closer to the ground in our survey of how different theories of adjudication would treat this concern. Theories of constitutional interpretation provide fairly restrictive criteria which determine what reasons or considerations are permitted to play a role in deciding constitutional cases. This makes sense. Given the pervasive sense in American jurisprudence that judicial review of legislative enactments is prima facie problematic, accounts of when that power may be exercised are designed to provide a justification for why a limited number of such "interventions" are legitimate. Since it would be impractical (and perhaps impossible) to canvass all theories of constitutional interpretation, I will examine three types of theories (prudential, structural, textual), which are representative of the range of views present in the literature and on the Court. We will look at how the effectiveness factor fares within each. 129

A constitutional theory is "prudential" if it recognizes and legitimates practical considerations as reasons for decision in constitutional cases. ${ }^{130}$ Philip Bobbitt describes it in this way: "[P]rudential argument is constitutional argument which is actuated by the political and economic circumstances surrounding the decision."131 Prudentialists include Justices Brandeis and Frankfurter and as its "most eloquent and creative exponent," Alexander Bickel.132 What distinguishes the prudentialist is that he goes beyond acknowledging the importance of these real world concerns; he recognizes them as the basis for and justification of decision. ${ }^{133}$

It is easy to see that a theory of constitutional interpretation that includes a prudentialist strain would permit the Court to consider the effect of its decisions on its continued ability to be effective over time. The concern with

128. Id. ("The judge's decision-his postinterpretive conclusions-must be drawn from an interpretation that both fits and justifies what has gone before, so far as that is possible.").

129. The characterizations of these types of theories I borrow from the topology of constitutional arguments presented by PHILIP BOBBITT, CONSTITUTIONAL FATE: THEORY OF THE CONSTITUTION (1982).

130. See id. at 61 .

131. Id.

132. Id. Prudentialism's contemporary defenders include, according to Bobbitt, Guido Calebrasi and Bruce Ackerman. Id. at 73.

133. Id.

Thus prudentialists generally hold that in times of national emergency even the plainest of constitutional limitations can be ignored. Perhaps others share that belief; but the prudentialist makes it a legitimate, legal argument, fits it into opinions, and uses it as the purpose for doctrines. It is this that makes him interesting to us. 
effectiveness is a type of prudential consideration. In fact, it is prudentialism working rather narrowly. Taking the effectiveness factor into account brings prudentialism about the Court itself into Supreme Court decision-making. One would think that prudentialism about the Court's own ability to maintain its effectiveness would be the most easily justified variant of prudential reasoning. If the Court loses power or effectiveness, its ability to achieve any other ends will diminish. Therefore, from the prudentialist's standpoint, safeguarding this ability is centrally important.

\section{v. Structural Theories}

A constitutional theory can be described as "structural" if it favors arguments which appeal to the relationships established by the Constitution between the various sources of power in government.134 For example a structural argument might be grounded in the constitutionally established relationship between the state and federal governments, between the different branches of the federal government, or between the government and the citizens generally. ${ }^{135}$ Structural arguments refer to the Constitution in its entirety rather than to particular passages-they look to the overall schema established by the document. Judicial decision-making is thus guided by the normative commitment to maintain the same balance as the Constitution is thought to embody.

Arguments from constitutional structure can probably be made in support of and in opposition to the permissibility of considering the effectiveness factor in constitutional decision-making. One could argue that the fact that the Court is accorded a certain amount of power by the constitutional structure implies the justifiability of acting to maintain that power. If the Court is in danger of losing effectiveness due to a loss of respect for its principled character, the Justices are authorized by structural arguments to decide in ways that will halt the decline in the Court's prestige. The argument from structure could thus be run in a way that would authorize the Court to take into account whether or not its decisions will be accepted as principled by its audience.

Alternatively, one could argue that the division of responsibilities ordained by the Constitution between the judicial, legislative and executive branches of government gives the Court very limited power. Just as the Court is at the mercy of the executive branch for the enforcement of its decrees, one might argue that the Court depends (and ought to depend) on the legislative and executive branches to secure and maintain the Court's power. Acting to protect its own image would be understood, according to this structural argument, as taking the Court outside of its permissible arena of action.

\section{vi. Textual Theories}

A textual approach to constitutional interpretation limits Court invalidation of legislative enactments to those plainly authorized by the text itself. ${ }^{136}$ The judge is supposed to import as little interpretive apparatus as possible into decision-making. Thus, even appeals to supporting documents

134. See id. at 74.

135. Id. ("Structural arguments are inferences from the existence of constitutional structures and the relationships which the Constitution ordains among these structures.").

136. Id. at 26. 
regarding what the drafters of the text intended certain provisions to mean are proscribed. The relevant meaning of the text is that which the common man or woman would discern. Philip Bobbitt names Justice Black as the chief exemplar of this view. 137 This understanding of a textual theory of constitutional interpretation would, most likely, prohibit consideration of the effectiveness factor. To the extent that the incorporation of this factor would dilute the absolute character of textual provisions, it would be considered improper. Moreover, there does not seem to be any direct or explicit textual support for the appropriateness of the Court's acting to preserve its own effectiveness.

\section{vii. Summary of the Argument Thus Far}

What has been established thus far is that the consideration of the effectiveness factor is permitted by some normative theories of adjudication and similarly by some theories of constitutional interpretation, but prohibited by others. Those theories of adjudication in which the distinction between law and politics is no longer firm, as well as those I have termed hybrid theories, permit the Court to count the effect of a decision on the Court's image as a reason to decide a particular way. However, those theories in which the lawpolitics distinction remains robust do not. According to these views, allowing the likely effect on the public perception of the Court to count as a reason on which the analysis may turn is seen as an illegitimate infiltration of the nonlegal into the legal.

- The "conclusion" that consideration of the effectiveness factor is permitted by some theories while prohibited by others establishes this factor as one among many principles of decision-making which are permitted by some theories of adjudication and interpretation but not by others. This is a more significant point than it might appear to be. For example, some normative theories of adjudication instruct the judge to consult something "outside" of the straightforwardly legal material (economic theories of efficiency for example) ${ }^{138}$ while others (those with a robust law-politics distinction) preclude this. ${ }^{139}$ Some theories of constitutional interpretation privilege the history and tradition of this country as a source of interpretive guidance, ${ }^{140}$ while others find such adherence to past understandings itself delegitimating. ${ }^{141}$ Thus, if one believes that consideration of the effectiveness factor is not properly a legal principle, then one believes that it is not a legal principle in a rather ordinary way.

137. Id.

138. See supra part II.A.3.a.i.

139. See supra part II.A.3.a.ii.

140. See BOBвITT, supra note 129, at 9-24.

141. See, e.g., Michael H. v. Gerald D., 491 U.S. 110 (1989). Justice Scalia, writing for the majority, upholds a California law which conclusively presumes that a child born to a married woman to be a child of the marriage. Id. at 130. In this case, the child in question was shown by blood tests to be the biological child of the man seeking paternity. Id. at 114. Scalia argued that the rights of an adulterous natural father are not protected explicitly in the text of the Constitution, nor are such rights traditionally safeguarded within our history and tradition. Id. at 125-27. Justice Brennan, dissenting, argues that such an appeal to history itself delegitimates the Constitution: "The document that the plurality construes today is unfamiliar to me. It is not the living charter that I have taken to be our Constitution; it is instead a stagnant, archaic, hidebound document steeped in the prejudices and superstitions of a time long past." Id. at 141 (Brennan, J., dissenting). 
Because we differ in our views about what normative theory of adjudication or what theory of constitutional interpretation is correct, we also differ about what reasons, or kinds of reasons, we think may properly be considered when making a decision. Consideration of appearance therefore cannot be said to be outlandish or non-legal in a troubling kind of way. When Scalia cries "realpolitik" in Casey,142 he seems to be claiming that there is something especially illegitimate about consideration of the effectiveness factor. He seems to be claiming that no one (not even someone who endorsed a different theory of adjudication than his own) could possibly think that consideration of the appearance factor (or the effectiveness factor) is properly a legal principle if they could see it for what it is, stripped of all the Casey plurality's talk about legitimacy. But this unmasking lacks force. Seen for what it is, the concern about effectiveness joins a long list of other concerns that are endorsed as appropriately legal reasons by some normative theories of adjudication while being rejected by others.

\section{b. Adding Factors Affects Outcomes}

So far we have established that consideration of the effectiveness factor is permitted by several theories of adjudication, while being prohibited by others. However, when we recast this factor as the consideration of how a decision will be perceived, it again seems troubling. There is a residue of unease. Justice Scalia captures this disquietude well in Casey: "[T]he notion that we would decide a case differently from the way we otherwise would have in order to show that we can stand firm against public disapproval is frightening." 143 Is it actually frightening? Or instead, is this statement simply an example of rhetorical and hyperbolic language used to disguise an ordinary phenomenon as something extraordinary and therefore illegitimate?

In order to answer this question, it makes sense to compare this situation (the inclusion of this new "appearance factor") with what happens when any factor is added to the list of factors already considered under an existing legal doctrine. For example, under the stare decisis doctrine, the factors traditionally considered before overruling a prior case include whether the old case was wrongly decided originally and whether there has been substantial reliance on the old rule, as well as concerns about the consistency, stability and predictability of legal doctrine. ${ }^{144}$ Imagine a hypothetical earlier version of stare decisis doctrine (SD1) that consists of the rule: Overrule an earlier incorrect decision. Suppose a case comes before the Supreme Court which implicates an older case which the Justices now believe was wrongly decided. If they were to follow SD1, the Justices would overrule the earlier wrongly decided case. But perhaps the circumstances of this new case make them reconsider the SD1. There has been substantial reliance on the old rule and, in taking note of this reliance, the Justices come to believe that overruling the earlier, wrongly decided case may, in some cases, cause injustice. In order to accommodate this new insight, they modify SD1, creating a new rule: Overrule

142. Planned Parenthood v. Casey, 112 S. Ct. 2791, 2883 (1992) (Scalia, J., dissenting).

143. Id.

144. See supra part I.B. 
a wrongly decided case except when there has been substantial reliance (SD2). 145

The effect of the addition of this new factor, substantial reliance, is clear: it will make the Court "decide a case differently from the way...[it] otherwise would have...."146 If the addition of a new factor could not have this effect, it would be superfluous. Adding a new factor into an analysis will always have the potential for tipping the balance, making the Court come out differently from the way that it would have without that factor. Modifying an existing legal doctrine effects change.

Scalia seems to imply that in allowing the appearance factor to play a role, the Court is going to reach the "wrong" legal answer. This view equates coming out differently from the way the Court would have without the addition of this new factor with getting an incorrect result. But the answer reached when the Justices include consideration of the appearance factor is not the "wrong" answer because the Justices would have reached a different result without the inclusion of this new factor. It is only the "wrong" answer if this new factor ought not be a part of stare decisis doctrine. Using the example above, changing the rule from SD1 to SD2 yields the "wrong" answer only if substantial reliance ought not be a part of a properly understood doctrine of stare decisis. The issue then is whether the appearance factor ought to be considered by the Court. The fact that its inclusion causes the Court to come out differently is simply not relevant.

Is there a way to read Scalia's objection in a more potent fashion? Since adding a new factor to an existing legal doctrine will almost always affect the results of applying the doctrine, one suspects there is more to Scalia's critique. Here is a possibility. Perhaps it is "frightening" for the Court to come out differently after adding the new appearance factor because the old rule already speaks to the issue of appearance. If one believes that following the old rule will always look principled then considering appearance as a separate factor will seem either redundant or misguided. 147

It would be redundant because one need only follow the old rule in order to look principled. It could also be seen as misguided (possibly even frightening) when we remember that the application of any factors to an actual case requires judgment. If one believes that applying the old rule in a principled fashion will always necessarily look principled, then the Court's suggestion that it must come out differently from the way the old rule's factors would require in order to satisfy the new and discrete appearance requirement, looks like a misapplication of this appearance requirement-an internal contradiction. Note, however, that this view rests on the claim that following the old rule will always look principled. This is the faith, discussed supra, that the principled character of principled decision-making is manifest. The truth of this claim is, however, far from obvious. Without that premise, this argument loses its force.

145. Of course, SD2 could be more complex. For example, it could require that the reliance be of a particular kind. For our purposes here, I am using a simplified example.

146. Casey, 112 S. Ct. at 2883 (Scalia, J., dissenting).

147. This is the faith in the manifest quality of principled decision-making discussed in part II.A.1. 


\section{B. All Things Considered}

\section{Effectiveness is Necessary for Legitimate Authority}

In this section I argue that those theories of adjudication that permit the Court to take appearance concerns into account are superior to those that do not $^{148}$ and that, all things considered, the fact that a decision is likely to detract from the public perception of the Court as a principle-guided institution is a reason to be weighed in reaching a decision in an individual case. My claim is this: in order for the Court to be able to justifiably compel compliance with its rulings in particular cases it must be effective enough to compel compliance with its pronouncements generally. Therefore, if the Court can protect its effectiveness through safeguarding its image, the Court ought to do so.

This claim raises the following question: Under what conditions may judges justifiably compel compliance with their directives? I will not analyze the necessary and sufficient conditions for legitimate political authority (a task beyond the scope of this article). Rather I will simply attempt to show that effective authority (also termed de facto authority) is a necessary component of legitimate political authority. This claim has been made by others, Joseph Raz for example. ${ }^{149}$ Raz's argument rests on his peculiar conception of what justifies legitimate authority generally. 150

My argument for the same conclusion rests on different grounds. Suppose the judiciary were significantly less powerful than our judiciary is today, such that the other branches of government and the citizens generally only occasionally deferred to the pronouncements of the courts as authoritative statements of the law. If this weak judiciary were to compel compliance with its orders in the few instances in which it were able, this would constitute the sporadic and arbitrary use of power. ${ }^{151}$ Moreover, those against whom this

148. For a discussion of which theories of adjudication permit the Court to take appearance concerns into account and which do not, see supra parts II.A.3.a.i-iv.

149. RAZ, supra note 108, at 56 ("There is a strong case for holding that no political authority can be legitimate unless it is also a de facto authority....If I am right then this is not a matter of meaning, but of normative justification.").

150. For Raz, a legitimate authority is an authority that provides service to those subject to its authority. RAZ, supra note 108, at 53-57. In Raz's view if an authority is a legitimate authority this entails both that the authority may justifiably compel compliance with its directives and that the subjects of the authority owe a corresponding duty to obey the directives of the authority. Id. This symmetry of justifiable compulsion and duty of obedience is not endorsed by others who write about the nature of authority. For example, Frederick Schauer believes that although a legitimate authority may justifiably compel compliance with its directives, subjects of that legitimate authority do not owe a corresponding duty of obedience to its directives-at least not one that flows from its status as a legitimate authority. Frederick Schauer, The Question of Authority, 81 GEO. L.J. 95, 110-15 (1992). Raz's "service" conception of authority requires that the authority generally, over time, be the better decision-maker than the subject, thus making the general deferral of decision-making power to the authority the right thing to do. RAZ, supra note 108, at 53-57. Raz calls this the "normal justification thesis." For Raz there are other constraints on this relation. For example, the authority's decision must rest on reasons that are reasons for the subject as well. Raz calls this the "dependence thesis." Id. at 47. In Raz's view, because one of the primary functions provided by political powers is the resolution of coordination problems, a political authority must be effective (i.e., able to provide this service) in order to be legitimate. Id. at 56.

151. Bickel makes a similar point when arguing that individual claims to legal justice in a particular case ought not to trump the societal need for an institution that can enforce such claims: "It is not justice for the Court to take unto itself, ad hoc, a function that it cannot, over the run of causes, perform with more benefit than harm to society." BICKEL, supra note 87, at 173. 
power was exercised would not be treated fairly. In order to avoid this unfairness, the court must be a de facto authority-able to compel compliance with its directives in most cases.

This unfairness is illustrated by the following hypothetical. Imagine that a high school has a rule requiring all students to remain on school grounds during the school day. Though the students have free periods (periods in which they are not in class), they are not permitted to leave the school grounds during those periods. They are free to play on the fields, study in the library, eat in the cafeteria or relax in the student lounges, but they must remain at school. The Handbook of School Regulations which lists this and other school rules provides that if any student is caught violating the rule, he or she will be brought before the School Disciplinary Board (the Board) which has the authority to determine whether the student has in fact been away from school grounds and if so what sanction (from among those listed in the handbook) is appropriate. Imagine further that in most cases in which the Board orders some sanction, nothing happens. The School administrators simply ignore the directives of the Board and the student simply flouts the sanction. Thus, the Board is an ineffective authority in the school environment. Against this background, the following situation arises. One day, Joe Unfortunate is caught leaving school to go to McDonald's for lunch. He is brought before the Board and the Board finds that he has violated the school rule. Assume that the Board generally reaches fair results given the evidence presented. Joe is suspended for two weeks. This time, however, the administration enforces the sanction. Joe is not allowed back in school and the suspension appears on his official record. Has Joe been treated fairly?

I think not. The unfairness of compelling Joe to comply with the directives of the Board when others have not been similarly compelled is the unfairness of not treating like cases alike-the traditional virtue of formal justice inherent in the Rule of Law ideal. If others, who have been suspended by the Board, have not been compelled to comply with the sanction while Joe has, he is not being treated as others like him are treated. In addition, Joe has not really been put on notice about what conduct is prohibited because when others have been "sanctioned" for similar conduct that sanction has not been enforced.

There are ways to play with this hypothetical so that sanctioning Joe begins to seem more fair. If the school administration had announced publicly that although it has, in the past, ignored the determinations of the Board, the administration will in the future enforce Board decisions, then sanctioning Joe for misconduct committed after the announcement would be fair. The above change cures both the defects identified above because it puts Joe on notice that the prohibited conduct really is proscribed and because it commits the school (understood as administration, Board and students) to treating like cases alike. The administration has announced its intention to enforce all sanctions issued by the Board from that moment forward, thereby assuring that all students sanctioned henceforth will, in fact, receive the same punishment. The fact that this change makes such a significant difference highlights the unfairness of the situation as originally described.

Try another permutation. Imagine that Joe is sanctioned by the Board for cheating and that this sanction is enforced by the administration. In this situation it is not clear whether Joe is being treated unfairly (though that moral 
intuition retains some force). This is so because cheating itself is wrong, independent of the school having made it so. Thus, where the conduct at issue is independently proscribed (morally), the inequity in arbitrary enforcement is less troubling. We thus might be more comfortable with the enforcement of sanctions against clearly heinous acts (murder, rape, etc.), not withstanding the arbitrariness of enforcement, because we feel confident that this conduct is unambiguously proscribed at some other level.152 However, without this recourse to some other standard, the arbitrary enforcement of judicial pronouncements remains troubling.

The hypothetical situation described above is relevantly different from the situation in which the school simply decides not to expend the resources needed to catch those who leave during the day-prosecutorial discretion. There is however an initial similarity: in both cases (the original hypothetical and prosecutorial discretion) only a tiny few of those who break the rule will actually be caught and punished. However, the circumstances surrounding the sporadic enforcement of sanctions in each case are importantly different. In the case of prosecutorial discretion, those in power have decided not to expend the resources necessary to catch all violators. ${ }^{153}$ In the hypothetical case, those in power have decided not to enforce the sanctions against all those who have been caught and judged by the adjudicative body. In the second instance the formal procedure is uncoupled from the effect that it legitimates. Punishment does not turn on the outcome of the procedure, but on something else, something fully and explicitly arbitrary. Whether punishment follows formal sanction depends only on the Court's ability to enforce the sanction in that instance. Thus the sanction, when enforced, loses its law-like quality. ${ }^{154}$

Finally, were the enforcement of the sanction against Joe and only Joe not innocent (i.e. motivated by no reason in particular), but instead the result of the fact that the other students caught and formally sanctioned were the children of people with political clout, the unfairness of the enforcement of the sanction against Joe and only Joe. would be heightened. The perniciousness of the reason (privileging class, race or other status) would provide an additional dimension to the wrong done to Joe. Were the Court to lose the ability to generally compel

152. The following example illustrates this well. Suppose that a new racist political party gains power in a state. This party has not changed the laws in the state (yet) so that, formally speaking, acts of violence against persons of the subordinated race are prohibited. However in practice these acts are becoming increasingly frequent. Even in the cases in which the perpetrators are caught, tried and sanctioned by the judiciary (who has not yet been corrupted by the new party), nothing happens to these perpetrators. The executive branch simply refuses to enforce the sanctions imposed by the courts. Now suppose that one such racist is caught looting a store owned by a member of the minority race. This perpetrator is tried and sanctioned. However, in this case the executive enforces the sanction-for a reason unconnected to a change in policy. Is the enforcement of "the law" against this racist fair? This is a difficult issue. What is important to note is that if one thinks it is fair, one thinks that because of the wrongness of the racist's actions in themselves, not because such conduct is against the law of the state. Therefore, the law itself cannot legitimize the use of coercion by the state unless that coercion is used in a non-arbitrary fashion. This example was suggested to me by Scott Brewer.

153. The perniciousness of some instances of prosecutorial discretion derives from the fact that the enforcement is guided by illegitimate reasons. The problem lies not in the lack of full enforcement but in the criterion relied on for selecting which potential violators or violations to pursue.

154. The use of "show trials" is an attempt to capture this law-like quality through coupling some formal procedure, though one admittedly lacking in substantive faimess and procedural safeguards, with the punishment. 
compliance with its directives, it is likely that the instances in which the Court would retain this power would be cases like the one just described. The weakened Court would likely be able only to compel the politically, economically or socially marginalized to comply with the directives.

In sum, because it would be unfair for the Court to force compliance with any of its directives unless it is powerful enough to insure compliance with its dictates generally, the Court has a reason to try to remain effective. Add to this the fact that the Court's ability to be effective is linked to its image. If the Court is perceived as a principle-guided body, it is more likely to be able to effectively compel compliance with its decisions. The Court thus has a powerful normative reason to make sure that its decisions appear principled.

\section{Candor}

Judges and courts may always have considered the likely effect of their decisions on the public perception of the Court-and for reasons similar to those discussed above. If so, then what is different about the current concern with appearance is not the addition of this new factor, but instead the candid and explicit recognition of the role it plays in decision-making. What we are now seeing, then, may be the breaking of a convention of opinion writing-a convention that governs what may be publicly acknowledged rather than what may in fact be taken into account.

Earlier I argued that in order for judges to appear principled, they must attend to appearing principled separately. ${ }^{155}$ This need is the result of a loss of faith in the manifest quality of principled decision-making. In this section, I consider the claim that nothing new really is going on. Rather, judges are simply writing about what they do more honestly. While I believe there has been a change in the reasons affecting judicial decisions and not merely a change in presentation, it would be difficult to prove this claim. Therefore, because the covert consideration of appearance concerns may have always played a role in judicial decision-making, I will here briefly consider the justifiability of this lack of candor.

\section{- a. Prima Facie Obligation}

In discussing whether judges have an obligation to be candid about the role of appearance in decision-making, we begin with a presumption in favor of candor. This presumption derives from general, and generally uncontroversial, ethical prohibitions against lying and deception. ${ }^{156}$ This prohibition against deception is doubly important in cases involving public officials. Because the public official is the repository of public trust, the lie told by the public official not only violates the general obligation to be truthful but in addition breaks a covenant between the official and the public. 157

155. See supra part II.A.1.

156. See SISSELA BOK, LYING 250-88 (1978) (citing passages from the works of Augustine, Aquinas, Bacon, Grotius, Kant, Sidgwick, Harrod, Bonhoeffer and Warnock).

157. DENNIS THOMPSON, POLITICAL ETHICS AND PUBLIC OFFICE 11-39, 116-22 (1987). There are, of course, exceptions to this general proposition, cases in which the public not only expects to be kept in the dark about certain matters but has, in some manner, consented to this practice. For example, the public may authorize through its representatives the use of covert military action in limited contexts. This authorization licenses the government to keep 
In the judicial context, there is yet a third reason why candor is required. As David Shapiro explains, "candor is the sine qua non of all other restraints on abuse of judicial power, for the limitations imposed by constitutions, statutes, and precedents count for little if judges feel free to believe one thing about them and to say another."158 Candor thus acts as a prophylactic; the requirement of publicity insures that the reasons on which decisions are based are at least minimally acceptable to the public. ${ }^{159}$ This is essentially Judge Posner's point as well. As Posner sees it, the publicity principle "will prevent the judge from rejecting consensus views." 160 More plausibly, it will prevent the judge from endorsing views that others perceive as wildly illegitimate. 161 Either way, publicity provides the opportunity for reaction to judicial reasoning, dialogue through the elective branches and formal and informal sanctioning of renegade judges.

\section{b. Collegiality and the Co-Signed Opinion}

There are of course exceptions to this prima facie obligation of candor. However, a justification is required for any such exception. The constraints of collegiality and the need to garner a majority may be particularly relevant in the judicial context.162 Although these constraints may seem to require less than complete candor, the accommodations to collegiality probably do not conflict with obligations of publicity at all. Where a Justice joins an opinion which she finds to reflect most, but not all, of the reasons she endorses, she does not necessarily deceive the reader. To the extent that such a practice coalesces with the expectations of the Court's audience, it is unproblematic. ${ }^{163}$ Whether or not

such actions secret (so long as the government action is within the scope of the authorization). These cases do not violate the publicity requirement. Rather, in requiring both publicity and consent at some phase in the process (here, in advance), they clearly comport with its precepts. See id. at 24-33 for a discussion of limited exceptions to the publicity requirement.

158. David L. Shapiro, In Defense of Judicial Candor, 100 HARV. L. REV. 731, 737 (1987).

159. Paul Gerwirtz has a similar view of the peculiar importance of candor as a judicial virtue. He explains it as follows:

Candor and sincerity are part of the distinctive process that legitimate judicial power-a process of decisionmaking and discourse whose requirements include writing opinions and giving reasoned justifications. These constraints help to promote the public accountability of judges and to stimulate judicial reflection and self-control. Without a requirement of candor, the constraints would be meaningless. Thus, misreading and other dishonesties in judicial opinions are generally more than craft flaws; candor in judicial reasoning is part of the morality of craft.

Gerwirtz, supra note 91 , at 667 .

160. POSNER, supra note 37 , at 134.

161. In The Federal Courts, Posner identifies the screening of unreasonable views as the function of the publicity requirement. RICHARD A. POSNER, THE FEDERAL COURTS 205 (1985) (arguing that what is termed "unprincipled" is "simply those grounds that at the particular historical moment are so generally rejected that they would never be announced as the true grounds of decision.").

162. As Kent Greenawalt explains, there are several reasons why it is important for the Justices not to write separately in cases dealing with important issues. For example, separate opinions with different bases do not make the Court appear as principled as would a single majority opinion. Moreover, different analyses which concur in the result only provide less guidance to people attempting to conform their conduct to law and to lower Court judges attempting to apply Supreme Court decisions. Greenawalt, supra note 84, at 1007.

163. Deception is practiced only where one conveys something which one does not believe to be true. Where one engages in a practice that it understood to carry a particular 
such a Justice is required to concur in the judgment only or to write separately, making explicit the additional reasons on which her view rests, as David Shapiro argues, ${ }^{164}$ is unclear. This determination depends on what the expectations of the Court's audience really are (which is an empirical matter).

\section{c. Paternalism and Self-Paternalism}

The most common arguments in favor of finding an exception to the prima facie obligation of candor in the judicial context are paternalistic or selfpaternalistic in nature. Either the public is thought to be unable to appreciate the relevant reasons for the Court's decision in the right way, thus justifying deception (paternalism); ${ }^{165}$ or, the public is claimed to have authorized the lack of candor in order to secure some important good (self-paternalism). To justify paternalism on the grounds suggested, one would need to show that the court's audience is impaired, unable to properly appreciate the reasons offered for decisions. Since we are talking about deceiving the public about the reasons on which a decision is based, the relevant public about whom the claim of impairment must be made is that public that reads and learns about the reasons offered for the decision. This is an educated public. Unless we are willing to call almost all of the citizenry impaired, which seems indefensible, deception about the real basis for decision on paternalistic grounds will be unjustifiable.

Alternatively, one could attempt to justify lack of judicial candor as a form of self-paternalism. Self-paternalism, because it is not true paternalism, does not require justification. The term self-paternalism is used to describe the following situation: an agent at time $\mathrm{T}_{1}$, believing that her judgment will be

meaning (though that practice taken literally could be understood to have a different meaning) one does not engage in deception if what one believes is consistent with the meaning understood to attach to one's actions.

164. Shapiro, supra note 158 , at $742-43$.

165. Bickel's critique of the Court's handling of Times Film Corp. v. City of Chicago, 365 U.S. 43 (1961), provides an example of a paternalistic justification for lack of candor. BICKEL, supra note 87, at 143. The issue before the Court in Times Film was whether a prior restraint on speech in the form of a required pre-screening censorship of a movie was constitutional. Because the film's owner refused to submit the film for licensing, the question was presented in the abstract. A majority of the Court determined that prior restraints on speech were constitutional in some very limited contexts, and thus upheld the District Court's dismissal of the Times Film Corp.'s action for an injunction against the licensing requirement. Bickel argues that the Court should never have granted certiorari, but having done so should have dismissed the case for lack of ripeness. Id. at 143. This position rests not on his belief that the case was not in fact ripe, but instead on Bickel's view that the Court's holding had the unfortunate effect of legitimating prior restraints.

Bickel does not trust the public to appreciate the subtleties of the Court's holding (that saying that prior restraints are not always unconstitutional is not to endorse them). He therefore advocates deception and dissimulation. He wants the Court to hold that the case is not ripe in order to avoid holding that prior restraints are hardly ever constitutional. He supports this ruse because he believes that a candid opinion would be misunderstood and that such a misunderstanding will have pernicious consequences for the country. See id. at 140.

Bickel's argument rests on an assumption about what the Court's audience can and cannot understand without being clear about who makes up this audience. As Gunther points out, to an unsophisticated reader the difference between a dismissal for lack of ripeness (which leaves the District Court's dismissal of the action for an injunction in place) and a ruling that the statute in question is not unconstitutional (having the same effect) may have little or no symbolic resonance. See Gunther, supra note 89, at 7. By contrast, for the informed court watcher or legal academic, the use of the "passive virtues" may detract from the Court's perceived legitimacy (as the dissimulation may be recognizable). Therefore this paternalism may not achieve its objective. 
impaired at time $T_{2}$, instructs at $T_{1}$ that her wishes at $T_{2}$ are to be ignored at that time. ${ }^{166}$ Rather than infringing liberty (as does true paternalism), selfpaternalism extends it. As Jon Elster explains, this conception of the event sees the act at $\mathrm{T}_{1}$ as "a privileged way of resolving the problem of weakness of the will; the main technique for achieving rationality by indirect means." 167 The classic example of self-paternalism is Ulysses' binding himself to the mast of his ship to avoid the temptation of the sirens. ${ }^{168}$ His request to have his later pleas to be cut down from the mast ignored constitutes self-paternalism.

How well does self-paternalism account for instances of lack of judicial candor? For this justificatory account to be applicable, one would have to believe that the public has consented (at some earlier time) to being deceived now. We would have so consented, presumably, because we recognized our collective inability to judge wisely at some future time. According to this view, we have not only delegated certain decision-making power to the Courts but, in addition, have authorized the Justices to tell us lies regarding the bases for their decisions. We have done this because we do not trust our own ability to properly evaluate the reasons for these decisions. While such a scenario is possible, it simply does not describe our own history.

\section{d. The Argument from Mystique}

An argument for lack of candor can be grounded in the Court's need for mystery, and, in particular, in its need for mystery surrounding how it safeguards its authority. As former Chief Judge Mikva of the United States Court of Appeals for the District of Columbia Circuit commented amid the furor occasioned by the opening of Justice Marshall's papers, "[t]he high bench, the black robe, the 'oyez, oyez,' are all part of trying to Wizard of Oz-ize us. But what's the power of a judge: It's partly mystical after all."169 It is difficult to evaluate how much, if any, mystery is necessary to perpetuate the power of the Court. It is worth noting however that mystery can be produced in different ways, ways which are more or less in conflict with the requirements of candor. Moreover, one might question the value of an institution whose power can only be maintained through ritual. 170

We can have mystery without deception. The Justices' black robes and the "oyez, oyez" remarked on by Judge Mikva are rituals that contribute to the aura surrounding the Court. Yet, they do not require a lack of candor. Secrecy about the content of intra-judge communication (memoranda, drafts of opinions, discussions, etc.) also contribute to this aura. But, secrecy is not equivalent to deception. Where the presence of a secret is itself known, this "shallow

166. See generally JON ELSTER, ULYSSES AND THE SIRENS: STUDIES IN RATIONALITY AND IRRATIONALITY (1984).

167. Id. at 37.

168. See id. at 36.

169. N.Y. TIMES, May 27, 1993, at 1, col. 1.

170. See generally CARL E. SCHORSKE, FIN-DE-SIECLE VIENNA: POLITICS AND CULTURE 116-80 (1961). Schorske argues in the essay "Politics in a New Key: An Austrian Trio" that the rise of Pan-Germanism, Christian-Socialism (both fascist in nature) and Zionism in Austria in the late 19th Century as potent challenges to liberalism depended in part on a politics that appealed to symbolism and ritual as weapons against the dry rationality of liberalism. Id. 
secret"171 is not ethically problematic. Because those from whom the secret is kept are aware that something is being kept from them, there is no deception. Thus, when Justices decline to make their papers public until after the deaths of all the Justices with whom they served, they are keeping shallow secrets. The fact that these papers are not made available is itself known. Moreover, the fact that Justices communicate and exchange memoranda is expected.

By contrast, were the Justices to base a decision, in part, on a factor that they resolved to keep secret, they would be engaging in deception. The secret reason would remain a "deep secret."172 The existence of something secret would itself be kept hidden. The public would not know the actual basis for the decision, nor would the public know that the decision was based on factors other than those expressed. Since it remains unclear how much mystery the Court needs to sustain its power, and since much of the necessary aura can be achieved with shallow secrets, the Court ought to refrain from the deception involved in the keeping of deep secrets.

In sum, the prima facie prohibition against deception remains intact. Neither a paternalistic nor a self-paternalistic argument suffices to justify the covert consideration of appearance. The Court's need for mystery (not itself clearly proved or adequately defended) seems to be met through the use of shallow secrets which are ethically unproblematic. In addition, even were dishonesty ethically permissible, it might yet be inadvisable. As Paul Gerwirtz explains, "dishonesty always creates the risk of its detection, and, with detection, harm to the court's stature...."173

\section{Self-Defeating}

But what if the candid consideration of the appearance factor by judges would itself erode public confidence in the Court. I argued earlier that the Court ought to take into account what effect its decisions will have on the perception of the Court in order to safeguard its ability to be effective over time. Were the direct and explicit attempt to do so to frustrate this end, such consideration would no longer be appropriate. Therefore, if a candid acknowledgment of the role this factor plays in legal analysis itself were seen as unprincipled, then explicitly and intentionally striving to appear principled will not succeed.

Striving to appear principled will be self-defeating if this striving to appear principled makes actually appearing principled impossible. The idea here is that there are some states which one cannot seek to bring about directly and intentionally. Attempting to do so is self-defeating because the very act of intending to bring about the state undermines the ability to achieve it. Jon Elster's account of states which can be achieved only as by-products while one is aiming at some other end is helpful here. ${ }^{174}$ Elster offers the example of

171. The term "shallow secret" as well as the contrasting "deep secret" come from Kim Lane Scheppele. See KIM L. SCHEPPELE, LEGAL SECRETS 21-22 (1988).

172. Id. (An example of a "deep secret" would be a secret extra-marital affair. The deceived spouse is unaware both that the affair is going on and that the cheating spouse is keeping something from him or her. Deep secrets generally provide no opportunity for consent and are consequently the most difficult to justify.).

173. Gerwirtz, supra note 91, at 671 .

174. See JON ELSTER, SOUR GRAPES: STUDIES IN THE SUBVERSION OF RATIONALITY (1983). One of Elster's most vivid examples is the familiar one of trying to fall asleep: 
Stendhal's confession in his diary that he desires to "become natural."175 By "natural," Stendhal means that he wants to become the sort of person who acts unselfconsciously, ${ }^{176}$ according to Elster. Stendhal goes about this first by trying to act as unselfconsciously as possible ${ }^{177}$ and then by trying to give the impression of naturalness in order to achieve the real thing. But as Elster explains, this strategy will not work: "the intentional element involved in the desire to appear indifferent is incompatible with the lack of intentionality that characterizes indifference." 178

We can now see why appearing principled is not like indifference. Indifference itself is defined by a lack of care about how one appears. The intentionality characteristic of trying to be unselfconscious is incompatible with the lack of intentionality characteristic of the state intended. Appearing principled, by contrast, is not defined by a lack of intentionality and, therefore, striving to appear principled will not be a necessarily self-defeating enterprise.

There is therefore nothing inherently self-undermining about striving to appear principled. However, attempting to appear principled may in fact turn out to be self-defeating (though it ought not to be) if others mistakenly believe that being principled precludes consideration of appearance. In this case, what causes the intentional striving to appear principled to be self-defeating is the mistaken view of others that being principled requires that one ignore appearance concerns. ${ }^{179}$ According to this view, striving to appear principled will involve the Court in an abandonment of principle.

It is hard to determine whether this view (that striving to appear principled is in conflict with being principled) is widely held. Data about the public's perception of the Court are spare and data about the public's reaction to the Court's recent inclusion of the appearance factor are non-existent. All we do have is public reaction to Casey itself, which drew public attention not because of the Court's novel consideration of appearance, but because the availability of abortion is an issue of great social concern. While some people favor and others deplore the substantive result reached in Casey regarding a

First, one tries to will an empty mind, to blot out all preoccupying thoughts. The attempt, of course, is contradictory and doomed to fail, since it requires a concentration of mind that is incompatible with the absence of concentration one is trying to bring about. Secondly, upon understanding that this is not going to work, one tries to induce a state of pseudo-resignation to insomnia. One acts, that is, as if one were persuaded that sleep is going to elude one, by taking up a book, having a snack or a drink, etc. But at the back of one's mind there is always the idea that one can cheat insomnia by ignoring it, and that the cheerful indifference to sleep will make sleep come at last. But then, thirdly, one understands that this is not going to work either. Next, real resignation sets in, based on a real, not a sham, conviction that the night will be long and bleak. And then, finally and mercifully, sleep comes. For veteran insomniacs, who know the game inside and out, the last stage never arrives. They know too well the benefits of resignation to be able to achieve it.

Id. at 45-46. In Elster's terms, the state of sleep is essentially a by-product, in that the attempt to bring it about is self-defeating.

175. Id. at 44.

176. Id. at 45 .

177. Elster explains that in order to achieve his end, Stendhal "formed the project to "say whatever comes into my head, to say it simply and without pretention; to avoid striving for an effect in conversation." Id. (quoting STENDHAL, OEUVRES INTIMES 117 (1981)).

178. Id.

179. For a discussion of this issue, see supra part II.A. 
woman's constitutional right to an early term abortion, a brief survey of press coverage reveals that the plurality's treatment of the stare decisis issue and particularly the discussion of the passages quoted earlier in this article has been viewed positively. ${ }^{180}$ If the Casey example is an indication, the Court's intentional and explicit attempt to appear principled should succeed.

Moreover, judges and others may be able to correct those misperceptions that exist about whether the principled decision-maker may consider appearance. In part, the Casey opinion attempts to do exactly that. It makes a case for the principled consideration of appearance. The opinion thus takes part in a dialogue (to which this article also contributes) about what reasons are appropriate grounds for decision. While it remains true that the principled consideration of appearance may be ultimately unsuccessful if others perceive such reasoning to be illegitimate, so far neither the general public nor the academic audience of the Court have reached a consensus on this view.

\section{Historical}

Though the value of an idea ought to be tied neither to its pedigree nor to its age, it is at the same time unlikely that an important and perhaps -normatively necessary approach to legal decision-making will be without precedent. As one would expect, the claim that the Court ought to pay attention to the effect its decisions have on the Court's prestige has been made before. In the academic literature the most famous defender of the importance of securing the Court's ability to be effective is Alexander Bickel. In The Least Dangerous Branch, Bickel advocates the prudential use of what he terms the "passive virtues" of adjudication as necessary to safeguard the esteem in which the Court is held. ${ }^{181}$ Briefly put, Bickel argues that the Supreme Court ought to use the doctrines that govern access to the Court (standing, mootness, ripeness and political question) in a somewhat manipulative way in order to insure that the Court does not rule on the merits in a case where doing so might undermine the Court's ability to be effective over time. 182

Bickel believes that the Justices must consider the long term health of the Court in order to carry out the mission he sees the Court as serving. In part this requires that the Court make some decisions for prudential reasons in order that it may make others governed entirely by what Bickel terms "principle." 183

180. See generally Linda Greenhouse, Souter Anchoring the Court's New Center, N.Y. TIMES, July 3, 1992, at A2; Linda Greenhouse, A Telling Court Opinion; The Ruling's Words Are About Abortion, But They Reveal Much About the Authors, N.Y. TIMES, July 1, 1992, at A1; Dick Lehr, Centrist Troika Slows the Right on High Court, BOSTON GLOBE, July 3, 1992, at 1; William Neikirk \& Glen Elsasser, Ruling Weakens Abortion Right, CHI. TRIB., June 30, 1992, at 1; David G. Savage, High Court Affirms Right to Abortion, But Allows Some Restrictions by States, L.A. TIMES, June 30, 1992, at A1.

181. BICKEL, supra note 87. See also Vincent Blasi, The Pathological Perspective and the First Amendment, 85 ColUM. L. REV. 449 (1985); George C. Christie, Why the First Amendment Should Not be Interpreted from the Pathological Perspective: A Response to Professor Blasi, 1986 DUKE L. J. 683 (1986); and accompanying defense, Vincent Blasi, The Role of Strategic Reasoning in Constitutional Interpretation: In Defense of the Pathological Perspective, 1986 DUKE L. J. 696 (1986).

182. BICKEL, supra note 87, at 132.

183. Gunther criticizes Bickel for his sometimes insistence on principled decision-making. Gunther, supra note 89, at 3 (arguing that the "novelty and vulnerability of the Bickel thesis" lies in its "emphasis on principle as the highest Court duty, but only in a limited sphere of Court actions; the $100 \%$ insistence on principle, $20 \%$ of the time."). 
For Bickel, deciding according to principle means deciding according to the applicable legal doctrine. While prudence, for him, stands outside of doctrine, Bickel understands prudence as the exercise of judgment about when to employ doctrine (principle) and when not-rather than as a principle that can play a role in doctrine.

For example, in a challenge to a state's anti-miscegenation law brought close on the heels of the Brown v. Board of Education 184 decision, Bickel advocates avoidance. While he admits that the available legal doctrines make invalidation of the state statute the stronger case, he argues that the political climate of the country could not handle such a volatile ruling at that time. 185 Because opponents of the Brown decision used the image of inter-racial dating as the rallying point of opposition to integration, Bickel argues that striking down an anti-miscegenation law at that time would have fueled resistance to Brown. ${ }^{186}$ Bickel's evaluation of what the Court ought to do in the antimiscegenation case is influenced by how he thinks the goal of integration can best be fulfilled and by how unnecessary damage to the Court's prestige can best be avoided. ${ }^{187}$

Bickel's advocacy of the passive virtues has been roundly criticized by Gerald Gunther as neither passive nor virtuous. ${ }^{188}$ As Gunther makes clear, a decision-making principle that dismisses a case as unripe when the traditional understanding of the ripeness doctrine would clearly show it to be ripe is not passive. Rather it is the active disposal of the case for other reasons. Moreover, in Gunther's view, the deployment of these "passive virtues" is dangerous. ${ }^{189}$ The most problematic aspect of Bickel's theory is its advocacy of dissimulation, its lack of candor. For Bickel the prudential judgment about when a case is to be dismissed in the service of the Court's ability to be effective is to be made covertly. 190 As Gunther points out, Bickel's theory actually requires the Justices to lie. ${ }^{191}$ They are to claim that they are deciding a case according to certain reasons, when in fact other reasons are operative and decisive.

The undoing of Bickel's own theory by Gunther's critique should not, however, prejudice us against a modified Bickelian approach. The candid recognition of the importance of the continued vitality of the Court and the

184. 347 U.S. 483 (1954).

185. BICKEL, supra note 87, at 174.

186. BICKEL, supra note 87, at 174.

187. BICKEL, supra note 87, at 174.

188. Gunther, supra note 89, at 24-25 (describing Bickel's virtues as " "passive' in name and appearance only").

189. Gunther, supra note 89, at 24 (arguing that Bickel's suggested treatment of the antimiscegenation case would involve compromising "the very principle-the impermissibility of racial classifications-that he purports to protect; here, surely, he endorses past court disregard of its raison d'être and asks that the disregard continue.").

190. Gunther, supra note 89, at 14 (commenting on Bickel's discussion of Times Film Corp. v. City of Chicago, 365 U.S. 43 (1961), Gunther points out that "there is to [Bickel] no 'manipulative dissimulation' when the Court concludes that the Constitution imposes no absolute ban on prior restraints but decides not to say so, decides to remain silent because of an 'assessment of the wisdom, the prudence of prior restraints[.]'"); Id. at 19 (discussing Bickel's proposed disposition of the contraception issue presented in Poe v. Ullman, 367 U.S. 497 (1961), Gunther criticizes that "[d]espite [Bickel's] emphasis on candor in the Court's relations with the political departments, he apparently does not believe that his 'deadlock' explanation ought to be the overt basis of decision." (emphasis added)).

191. Gunther, supra note 89, at 14. 
explicit incorporation of "effect on effectiveness" as a factor to be considered by the Court constitute a defanged prudence of a Bickelian heritage. Moreover, in following Bickel by claiming that the Court ought to take account of effectiveness, we need not endorse Bickel's own accommodation of that value. To endorse the importance of incorporating prudential judgment about Court effectiveness in legal decision-making is not to endorse Bickel's own judgment of how to balance that concern against other important values in a particular case. Bickel may have been wrong about how to balance the claim involved in the challenge to the anti-miscegenation law against the potential damage to the Court that he perceived might flow from that decision. However, accepting the thesis advanced in this article commits one to come part of the way with Bickel. One must accept that the Court may, in making a principled decision, take into consideration the effect of such a decision on Court effectiveness.

Interestingly, Bickel may also have been wrong in his prediction that an unpopular result (striking down anti-miscegenation laws) would in fact detract from the esteem in which the Court was held. At times it is by steadfastly adhering to an unpopular view that the Court appears principled. ${ }^{192}$ In fact, a commonplace trope of opinion-writing makes use of exactly this legitimation strategy. The opinion writer calls attention to something he or she considers to be an illegitimate grounds for decision (a personal characteristic or known political view for example), highlighting that were this illegitimate reason used as a basis for decision, it would lead the judge to reach a particular result.193 Thus, the fact that the judge reaches a contrary decision shows that the judge has decided in the appropriate manner and according to the right reasons.

Bickel seems to equate the unpopularity of a decision with the decision's inability to engender respect. They are not the same thing. Thus, when I claim that the Court ought to take into account how a decision will affect the Court's ability to be effective, I am not instructing the Court to take the pulse of the nation on substantive issues before reaching a decision. Rather the thesis advanced in this article requires that the Court offer reasons for its decisions that are likely to be accepted by others as principled and reasonable. 194 The test of public acceptability thus operates in my theory at a more abstract level than does Bickel's. Rather than looking for acceptable outcomes, the judge is searching for acceptable reasons.

192. The public reaction to the flag burning cases provides an apposite example.

193. See West Virginia State Bd. of Educ. v. Barnette, 319 U.S. 624, 646 (1943) (Frankfurter, J., dissenting). In Barnette, Frankfurter calls attention to his status as a jew to legitimate his finding against another group of political outsiders, Jehovah's Witnesses. On the one hand, "[o]ne who belongs to the most vilified and persecuted minority in history is not likely to be insensible to the freedoms guaranteed by our Constitution," but on the other hand, "[a]s a member of this Court I am not justified in writing my private notions of policy into the Constitution, no matter how deeply I may cherish them or how mischievous I may deem their disregard." Id. at 646-47. See also ROBERT M. COVER, JUSTICE ACCUSED: ANTISLAVERY AND THE JUDICIAL PROCESS (1975) (explaining that the opinions of Justices McLean and Story on the Supreme Court and Shaw of Massachusetts, upholding the Fugitive Slave Acts, gained legitimacy in the eyes of contemporaries from the fact that their strong anti-slavery positions were widely known).

194. See discussion on independence supra part II.A.2. 


\section{Neo-Prudentialism}

Prudentialism, traceable directly to Bickel, is enjoying a renaissance. Anthony Kronman, for example, touts the virtues of the prudential outlookhumility, judgment, and distrust of grand, overarching or organizing legal theories-in his recent book The Lost Lawyer. ${ }^{195}$ This neo-prudentialism has a self-consciously traditionalist outlook. ${ }^{196}$ It is conservative in the Burkean sense, only very cautiously departing from the wisdom embodied in the practices of the past.197 If this article joins in the current enthusiasm for Bickelian prudentialism, it does so only in the following limited way. Neoprudentialism emphasizes humility. In the hands of Kronman, this humility can lead to an untenable deference to the past. However, it can also lead to caution and, more importantly, to a healthy respect for the views of others. What I take from prudentialism is this humility. The view I have offered in this article adopts that aspect of neo-prudentialism in arguing that the reason-giving institution in our pluralist society must offer reasons for its decisions that other reasonable people can be expected to accept as principled. ${ }^{198}$

\section{CONCLUSION}

The Supreme Court's recent attention to appearance as a discrete and important element in decision-making is to be commended. The Court must justify its decisions-a process that requires attention to how the reasons given for decisions are received. In order for a decision to succeed in justifying the result for which it is offered, it must appear principled. It also must be based on reasons which are likely to be acceptable to others who endorse different substantive commitments. In addition, because the Court's power depends on its image, in order to maintain its effectiveness, the Court must take care to preserve the esteem in which it is held. This effectiveness is necessary (normatively speaking) in order for the court to justifiably compel compliance with its directives in individual cases. In sum, not only is the Court permitted to take appearance concerns into account in legal decision-making, all things considered, the Justices ought to do so in order to properly and justifiably fulfill the judicial function.

195. ANTHONY T. KRONMAN, THE LOST LAWYER: FAILING IDEALS OF THE LEGAL PROFESSION (1993). See also Anthony T. Kronman, Alexander Bickel's Philosophy of Prudence, 94 YALE L.J. 1567, 1572 (1985) (defining prudence as "a skeptical suspicion of abstract arguments and an affectionate (though not uncritical) regard for the organic mysteries of established institutions.").

196. See, e.g., Anthony T. Kronman, Precedent and Tradition, 99 YALE L.J. 1029 (1990) (arguing that the past ought to be respected because it is past; because it is the repository of our culture and, as such, that by which we are distinctly human.). For an insightful critique of Kronman's traditionalism, see David Luban, Legal Traditionalism, 43 STAN. L. REV. 1035 (1991). See also KRONMAN, supra note 195, at 154-62; David B. Wilkins, Practical Wisdom for Practicing Lawyers: Separating Ideals from Ideology in Legal Ethics, 108 HARV. L. REV. 458 (1994).

197. See, e.g., THE PHILOSOPHY OF EDMUND BURKE (Louis I. Bredvold \& Ralph G. Ross eds., 1960).

198. This phrase self-consciously adopts Rawls's terminology. See RAWLS, supra note 110 , at $212-54$. 
,

HeinOnline -- 37 Ariz. L. Rev. 11521995 